\title{
The impact of comorbidity on cancer survival: a review
}

This article was published in the following Dove Press journal:

Clinical Epidemiology

I November 2013

Number of times this article has been viewed

\section{Mette Søgaard'}

Reimar Wernich Thomsen'

Kristine Skovgaard Bossen ${ }^{2}$

Henrik Toft Sørensen'

Mette Nørgaard'

'Department of Clinical Epidemiology, Institute of Clinical Medicine, Aarhus University Hospital, Aarhus, Denmark; ${ }^{2}$ Danish Cancer Society, Copenhagen, Denmark
Correspondence: Mette Søgaard Department of Clinical Epidemiology, Aarhus University Hospital, Olof Palmes Allé 43-45, 8200 Aarhus N, Denmark Tel +4587168063

Fax +4587167215

Email mette.soegaard@ki.au.dk
Background: A number of studies have shown poorer survival among cancer patients with comorbidity. Several mechanisms may underlie this finding. In this review we summarize the current literature on the association between patient comorbidity and cancer prognosis. Prognostic factors examined include tumor biology, diagnosis, treatment, clinical quality, and adherence.

Methods: All English-language articles published during 2002-2012 on the association between comorbidity and survival among patients with colon cancer, breast cancer, and lung cancer were identified from PubMed, MEDLINE and Embase. Titles and abstracts were reviewed to identify eligible studies and their main results were then extracted.

Results: Our search yielded more than 2,500 articles related to comorbidity and cancer, but few investigated the prognostic impact of comorbidity as a primary aim. Most studies found that cancer patients with comorbidity had poorer survival than those without comorbidity, with 5 -year mortality hazard ratios ranging from 1.1 to 5.8. Few studies examined the influence of specific chronic conditions. In general, comorbidity does not appear to be associated with more aggressive types of cancer or other differences in tumor biology. Presence of specific severe comorbidities or psychiatric disorders were found to be associated with delayed cancer diagnosis in some studies, while chronic diseases requiring regular medical visits were associated with earlier cancer detection in others. Another finding was that patients with comorbidity do not receive standard cancer treatments such as surgery, chemotherapy, and radiation therapy as often as patients without comorbidity, and their chance of completing a course of cancer treatment is lower. Postoperative complications and mortality are higher in patients with comorbidity. It is unclear from the literature whether the apparent undertreatment reflects appropriate consideration of greater toxicity risk, poorer clinical quality, patient preferences, or poor adherence among patients with comorbidity.

Conclusion: Despite increasing recognition of the importance of comorbid illnesses among cancer patients, major challenges remain. Both treatment effectiveness and compliance appear compromised among cancer patients with comorbidity. Data on clinical quality is limited.

Keywords: comorbidity, cancer, diagnosis, treatment, survival

\section{Introduction}

It is essential to personalized medicine to understand how patient characteristics such as age and coexisting diseases (comorbidity) affect cancer detection, treatment, and outcome. With more than $60 \%$ of cancer patients diagnosed at age 65 or older in high-income countries, ${ }^{1}$ many patients have comorbidities that complicate the decision-making process. Because the elderly and persons with comorbidity are often underrepresented in clinical trials, ${ }^{2,3}$ information regarding treatment effectiveness is 
often extrapolated from studies of younger patients without comorbidity.

Several studies have shown poorer survival among cancer patients with comorbidity, ${ }^{4-11}$ but the underlying mechanisms remain unclear. In recent decades 5-year survival rates have improved among cancer patients without comorbidity, but not among patients with severe comorbidity. ${ }^{4-6}$ An understanding of how comorbidity affects survival in patients with cancer is needed to guide clinical practice. We therefore reviewed the literature on the association between comorbidity and survival among patients with three of the most commonly diagnosed cancers: colon cancer, breast cancer, and lung cancer.

\section{Methods}

\section{Definition and measurement of comorbidity}

Comorbidity has been defined as "any additional clinical entity that has existed or that may occur during the clinical course of a patient with an index disease under study." ${ }^{12,13}$ The term "multimorbidity" is often used interchangeably with "comorbidity" but has a slightly different meaning. Multimorbidity refers to the coexistence of $\geq 2$ illnesses without identifying an index disease. ${ }^{14}$ Comorbidity must also be distinguished from complications that arise as a consequence of the cancer or its treatment. A number of studies have examined the prognostic impact of patients' "performance status" at the time of cancer diagnosis. Performance status is a measure of a cancer patient's wellbeing defined as the amount of normal daily activity the patient can maintain. ${ }^{15-17}$ However, performance status is affected by cancer, complications of cancer, and comorbid conditions. ${ }^{18}$ Therefore, measures of comorbidity must be distinguished from measures of performance status.

Data on comorbid diseases are available from different data sources, such as medical records, administrative databases, physical examinations, and self-reports using questionnaires. ${ }^{19-21}$ Comorbidity can be assessed by counting the number of coexisting diseases diagnosed in a cancer patient or by using a comorbidity index that combines the number and severity of the diseases. The most widely used index is the Charlson Comorbidity Index (CCI). The original Charlson measure was constructed to predict 1 -year mortality in 559 medical patients as well as 10-year mortality rates for death attributable to comorbid diseases among 685 breast cancer patients. ${ }^{22}$ The index is based on 19 distinct medical disease categories. Each condition has a weight assigned from 1 to 6 , derived from the relative risk estimates obtained from a regression model. The CCI score is the sum of weights for all prevalent conditions. The score can theoretically range from 0-33 but was collapsed into categories of $0,1-2,3-4$, and $\geq 5$ in its initial presentation..$^{22,23}$

\section{Literature search}

We searched PubMed, MEDLINE and Embase to identify and summarize existing information on the association between comorbidity and cancer survival in patients with colon cancer, breast cancer, and lung cancer. We used the following keywords to identify potentially useful articles: "comorbidity," "multimorbidity," and "coexisting diseases." In addition, we searched for articles on the following prevalent comorbid diseases: diabetes, cardiovascular diseases, chronic pulmonary disease, and dementia. Furthermore, we queried the databases using the terms "colon cancer," "breast cancer," "lung cancer," and "comorbidity" combined with such terms as "pathogenesis," "histology," "differentiation," "stage," "diagnosis," "centralized treatment," "specialized treatment," "patient volume," and "surgeon volume." We limited our search to English-language articles published within the last 10 years. All searches were performed at the end of November 2012. Our PubMed search strategy is described in detail in Table S1.

Overall, we identified 2,692 potentially eligible articles (Figure 1). The first author (MS) reviewed the titles and abstracts and removed articles not relevant to comorbidity and cancer survival. The information summarized in this review was gleaned from the remaining articles and prior publications cited by these articles.

\section{Results \\ Prevalence of comorbidity among cancer patients}

As shown in Table 1, comorbidity is common in patients with colon cancer $(14 \%-68 \%)$, breast cancer $(20 \%-35 \%)$, and lung cancer $(26 \%-81 \%)$. A recent Danish populationbased cohort study found that elderly patients with colorectal and lung cancer had a higher prevalence of comorbidity than an age- and sex-matched comparison cohort from the general population, as measured by CCI scores (CCI score of 1 or $2: 12.3 \%$ vs $9.6 \%$ and CCI score of $\geq 3: 5.6 \%$ vs $4.0 \%) .{ }^{24}$ The probable reason for these findings is that known risk factors for colorectal or lung cancer, such as smoking, obesity, and physical inactivity, are also common risk factors for non-cancer diseases such as ischemic heart disease. 

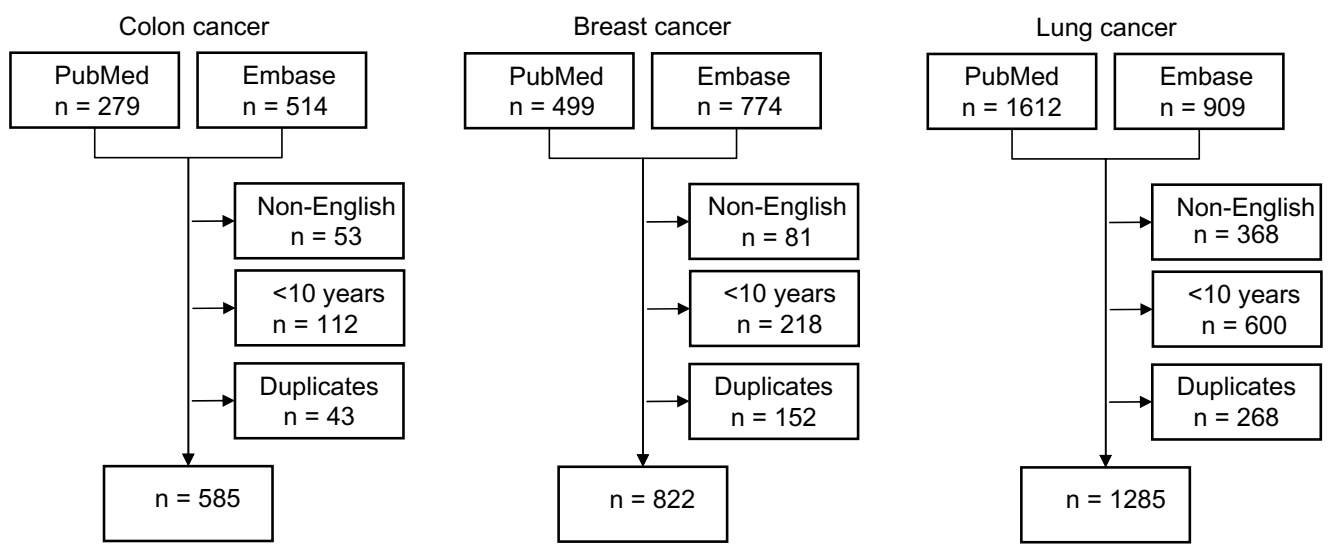

Figure I Flowchart of the studies retrieved from the PubMed, MEDLINE and Embase literature search.

As average life expectancy increases in Western countries, the proportion of elderly cancer patients also is expected to increase..$^{25}$ Because the prevalence of comorbidity increases with age, the number of cancer patients with comorbidity will increase concomitantly. This is indicated in a US study of 49,646 women aged 67 years or older with breast cancer in the Surveillance, Epidemiology, and End Results (SEER)-Medicare linked data set. Among these patients, $23 \%$ of women aged $85-89$ years and $11.2 \%$ of women aged 67-69 years had severe comorbidity. ${ }^{26}$ In a study from The Netherlands, $53 \%$ of patients aged $60-74$ years were found to have at least one comorbidity, and this proportion increased to $63 \%$ in patients aged 75 years and older. $^{24}$

\section{Impact of comorbidity on cancer survival}

Most observational studies have found that cancer patients with comorbidities have poorer survival than patients without comorbidities. ${ }^{4-11,24,28-30}$ Cohort studies with 5-7 years of follow-up have reported 1.1- to 5.8-fold higher mortality for breast cancer patients with any comorbidity compared to patients with no comorbidity., ${ }^{4,20,26,31,32}$ Similarly, studies of patients with colon cancer have reported 1.2- to 4.8-fold higher 5-year mortality for patients with comorbidity versus without comorbidity. ${ }^{5,8,9,25,32,34}$ Correspondingly, mortality in patients with lung cancer is 1.1 to 1.5 times higher for patients with comorbidity in studies with 1-5 years of follow-up. ${ }^{7,29,34,35}$ Not surprisingly, if survival among patients with a particular type of cancer is generally very poor, the additional effect of comorbid diseases on mortality on a relative scale is small. ${ }^{34,36,37}$ Thus, the relatively lower prognostic impact of comorbidity among lung cancer patients is probably due to a 1 -year mortality rate above $70 \%$ even among otherwise healthy patients. ${ }^{24}$
Stage at diagnosis influences decisions about the appropriate course of treatment and is strongly associated with cancer survival. Thus, stage-specific analyses may provide more insight into the association between comorbidity and cancer survival. Among 62,591 women diagnosed with early-stage breast cancer in Denmark during 1990-2008, the adjusted hazard ratios (HRs) for allcause mortality were 1.45 (95\% confidence interval [CI]: $1.40-1.51)$ for patients with low comorbidity, 1.52 (95\% CI: 1.45-1.60) for patients with moderate comorbidity, and 2.21 (95\% CI: 2.08-2.35) for patients with severe comorbidity, compared to patients without comorbidity. Median follow-up time was 8.2 years. ${ }^{6}$ Recently, Patnaik et al ${ }^{28}$ used the SEER-Medicare linked data set to determine the effect of 13 distinct comorbid conditions on survival and all-cause mortality among 64,034 breast cancer patients aged 66 years or older from 1992 to 2000. Patients with any of the 13 comorbidities had lower rates of 5-year survival than patients with no comorbidities. In addition, stage I cancer patients with serious comorbid conditions had survival rates similar to stage II cancer patients without comorbidities. Thus, patients with early-stage cancers and significant comorbidities had outcomes comparable to patients with later-stage tumors.

A key question is whether the higher mortality observed in cancer patients with comorbidity stems from their comorbidity or whether their cancer-specific mortality is elevated. In a recent Danish cohort study of 6,325 patients aged $\geq 70$ years with breast, lung, colorectal, prostate, or ovarian cancer, 5-year all-cause mortality increased with higher levels of comorbidity. ${ }^{24}$ For 5-year cancer-specific mortality, however, comorbidity was associated with increased rates only in patients with lung cancer (5-year HR for CCI score $\geq 3$ vs CCI score of $0=1.29$ [95\% CI: $1.03-1.60]$ ). 
Table I Results of selected studies on the association between comorbidity and treatment

\begin{tabular}{|c|c|c|c|c|c|c|}
\hline Author & Design, country & $\begin{array}{l}\text { Study } \\
\text { duration }\end{array}$ & $\begin{array}{l}\text { No of } \\
\text { patients }\end{array}$ & Study population & $\begin{array}{l}\text { Comorbidity } \\
\text { assessed }\end{array}$ & \% witl \\
\hline \multicolumn{7}{|c|}{ Colon cancer } \\
\hline Hu et $\mathrm{a}^{102}$ & Cohort study, USA & $|99|-2005$ & 12,265 & $\begin{array}{l}C C, \geq 65 \text { years, } \\
\text { stage III }\end{array}$ & $\mathrm{CCl}^{22}$ & $\begin{array}{l}\text { Overa } \\
\mathrm{CCl} \mathrm{I:} \\
\mathrm{CCl} \geq\end{array}$ \\
\hline $\begin{array}{l}\text { Kennedy } \\
\text { et } \mathrm{al}^{89}\end{array}$ & Cohort study, USA & $2005-2008$ & 5,914 & $\begin{array}{l}C C, \geq 65 \text { years, } \\
\text { stage III }\end{array}$ & $\begin{array}{l}\text { List of individual diseases } \\
\text { BMI } \\
\text { ASA score }\end{array}$ & N/A \\
\hline
\end{tabular}

ASA score

\begin{tabular}{|c|c|c|c|c|c|c|}
\hline $\begin{array}{l}\text { Morris } \\
\text { et } a^{91}\end{array}$ & $\begin{array}{l}\text { Population-based } \\
\text { cohort study, UK }\end{array}$ & 1998-2006 & 162,920 & CRC, all stages & $\mathrm{CCl}$ & $\begin{array}{l}\text { Overall: } 14.1 \% \\
\mathrm{CCl} \text { I: } 8.4 \% \\
\mathrm{CCl} 2: 4.0 \% \\
\mathrm{CCl} \geq 3: 1.7 \%\end{array}$ \\
\hline $\begin{array}{l}\text { van } \\
\text { Steenbergen } \\
\text { et } \mathrm{al}^{93}\end{array}$ & $\begin{array}{l}\text { Population-based } \\
\text { cohort study, The } \\
\text { Netherlands }\end{array}$ & $200 \mathrm{I}-2007$ & 1,637 & CC, stage III & $\mathrm{CCl}$ & $\begin{array}{l}\text { Overall: } 51.2 \% \\
\mathrm{CCl} \mathrm{I}: 28.3 \% \\
\mathrm{CCl} \geq 2: 22.8 \%\end{array}$ \\
\hline $\begin{array}{l}\text { Winget } \\
\text { et al }{ }^{105}\end{array}$ & $\begin{array}{l}\text { Population-based } \\
\text { cross-sectional study, } \\
\text { Canada }\end{array}$ & & 772 & $\begin{array}{l}\text { Surgically treated } \\
\text { CC, stage III }\end{array}$ & $\mathrm{CCl}$ & Overall: $32 \%$ \\
\hline $\begin{array}{l}\text { Bradley } \\
\text { et al }{ }^{94}\end{array}$ & Cohort study, USA & $1997-2000$ & 4,765 & $\begin{array}{l}\mathrm{CC} \text { patients } \\
\text { who underwent } \\
\text { resection, all stages }\end{array}$ & $\mathrm{CCl}$ & $\begin{array}{l}\text { Overall: } 34.2 \% \\
\mathrm{CCl} \mathrm{I}: 2 \mathrm{I} .4 \% \\
\mathrm{CCl} \geq 2: 12.7 \%\end{array}$ \\
\hline
\end{tabular}

Lemmens

et $\mathrm{al}^{138}$
Cohort study, The

Netherlands
1995-1999 279

(1)

$\mathrm{CC}$ patients $\quad \mathrm{CCl}$

who underwent

resection, stage I-III
Overall: $47.8 \%$

I: $28.1 \%$

$\mathrm{Cl} \geq 2: 19.6 \%$

\section{/A}

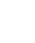


End points assessed

Results related to comorbidity

Main conclusion

Chemotherapy initiation and completion

Risk of surgical complication 30-day postoperative mortality

30-day postoperative mortality

Receipt of chemotherapy

Consultation with medical oncologist within 6 months of diagnosis

Receipt of standard treatment

Adjuvant chemotherapy initiation, completion, and evaluation by oncologist

Risk of surgical complication
Adj ORs of chemotherapy initiation compared with those with $\mathrm{CCl}=0$ :

$\mathrm{CCl}$ I: 0.63 (95\% Cl: 0.57-0.70)

$\mathrm{CCl} \geq 2: 0.37$ (95\% Cl: 0.33-0.42)

Adj ORs of chemotherapy completion compared to

those with $\mathrm{CCl}=0$ :

CCI I: 0.87 (95\% Cl: 0.75-I.0I)

$\mathrm{CCl} \geq 2: 0.63$ (95\% Cl: 0.52-0.75)

Adj OR of postoperative complications

$\mathrm{BMI}<$ I8: 0.9I (95\% Cl: 0.62-I.34)

BMI 25-29.9: 1.22 (95\% Cl: I.04-I.43)

BMI 30-49: I.26 (95\% Cl: I.05-I.49)

COPD: I.84 (95\% Cl: I.49-2.27)

ASA2 (severe): I.29 (95\% Cl: I. I0-I.52)

ASA3 (life threatening): I.65 (95\% Cl: I.26-2. I6)

Adj ORs of 30-day postoperative mortality:

ASA2 (severe): I.59 (95\% Cl: 0.98-2.58)

ASA3 (life threatening): 2.58 (95\% Cl: I.4I-4.72)

Adj ORs of death within 30 days of surgery compared

to those with $\mathrm{CCl}=0$ :

CCl I: 2.12 (95\% Cl: I.99-2.26)

CCl 2: 2.46 (95\% Cl: 2.26-2.68)

$\mathrm{CCl} \geq 3: 4.5 \mathrm{I}$ (95\% Cl: 4.06-5.0I)

Adj ORs of receiving chemotherapy compared to those

with $\mathrm{CCl}=0$ :

CCI I: 0.7 (95\% Cl: 0.5-0.9)

$\mathrm{CCl} \geq 2$ : 0.4 (95\% Cl: $0.3-0.6)$

$36 \%$ of patients with $\mathrm{CCl} \geq \mathrm{I}$ did not consult an oncologist vs

$12 \%$ of patients with $\mathrm{CCl}=0$.

Adj RR was I.6I (95\% Cl: I.24-2.09) for not having a

consultation and $\mathrm{I} .55(95 \% \mathrm{Cl}$ : I.3I-I.83) for not receiving

guideline-recommended treatment, compared to patients

with $\mathrm{CCl}=0$.

Adj ORs of chemotherapy initiation compared to those

with $\mathrm{CCl}=0$ :

$\mathrm{CCl} \mathrm{I}: 0.83$ (95\% Cl: $0.70-\mathrm{I} .04)$

$\mathrm{CCl} \geq 2: 0.62$ (95\% Cl: 0.49-0.78)

Adj ORs of chemotherapy completion compared to those

with $\mathrm{CCl} 0$ :

$\mathrm{CCl} \mathrm{I}:$ I.06 (95\% Cl: 0.77-I.44)

$\mathrm{CCl} \geq 2: 0.58$ (95\% Cl: $0.38-\mathrm{I} .6 \mathrm{I})$

Adj ORs of oncology evaluation compared to those

with $\mathrm{CCl}=0$ :

CCl I: I.25 (95\% Cl: 0.98-I.59)

$\mathrm{CCl} \geq 2:$ I.6I (95\% Cl: I.I7-2.20)

Adj ORs of surgical complications compared with patients with $\mathrm{CCl}=0$ :

Any comorbidity: I.I (95\% Cl: 0.9I-I.4)

Previous malignancy: I.2 (95\% Cl: 0.7-2.I)

CVD: 0.9 (95\% Cl: 0.5-I.5)

COPD: I.8 (95\% Cl: 0.7-4.7)

Diabetes: 0.6 (95\% Cl: 0.I-I.4)

Hypertension: 0.7 (95\% Cl: 0.4-I.4)

DVT: 9.0 (95\% Cl: I.I-27.9)
Patients with comorbidity are less likely to initiate and complete chemotherapy.

Patients with comorbidity and obesity are more likely to experience complications after surgery. Short-term mortality after surgery is higher among patients with comorbidity.

Short-term mortality after surgery is higher among patients with comorbidity.

Patients with comorbidity are less likely to receive chemotherapy.

Patients with comorbidity are less likely to be referred to a medical oncologist and to receive treatment consistent with guidelines.

Patients with comorbidity are less likely to initiate and complete chemotherapy, but more likely to be evaluated by an oncologist.

Odds of complications are higher among patients with COPD and DVT, but not among those with previous malignancy, CVD, diabetes, and hypertension. 
Table I (Continued)

\begin{tabular}{|c|c|c|c|c|c|c|}
\hline Author & Design, country & $\begin{array}{l}\text { Study } \\
\text { duration }\end{array}$ & $\begin{array}{l}\text { No of } \\
\text { patients }\end{array}$ & Study population & $\begin{array}{l}\text { Comorbidity } \\
\text { assessed }\end{array}$ & $\%$ with comorbidity \\
\hline Luo et $\mathrm{al}^{95}$ & Cohort study, USA & $1992-1999$ & 7,569 & $\begin{array}{l}\text { CC, } 66-99 \text { years, } \\
\text { stage III }\end{array}$ & $\mathrm{CCl}$ & $\begin{array}{l}\text { Overall: } 32.3 \% \\
\mathrm{CCl} \text { I: } 20.5 \% \\
\mathrm{CCl} 2: 7.4 \% \\
\mathrm{CCl} \geq 3: 4.4 \%\end{array}$ \\
\hline
\end{tabular}

\begin{tabular}{|c|c|c|c|c|c|c|}
\hline $\begin{array}{l}\text { Neugut } \\
\text { et al }{ }^{129}\end{array}$ & $\begin{array}{l}\text { Population-based } \\
\text { cohort study, USA }\end{array}$ & $1995-1999$ & 3,733 & $\begin{array}{l}C C, \geq 65 \text { years, } \\
\text { stage III }\end{array}$ & $\mathrm{CCl}$ & $\begin{array}{l}\text { Overall: } 51.7 \% \\
\text { CCI I: } 29.5 \% \\
C C I>I: 22.2 \%\end{array}$ \\
\hline Gross et al ${ }^{108}$ & Cohort study, USA & $1993-1999$ & 5,330 & $\begin{array}{l}C C, \geq 65 \text { years, } \\
\text { stage III }\end{array}$ & List of individual diseases & $\begin{array}{l}\text { CHF: } 16.0 \% \\
\text { Diabetes: } 17.8 \% \\
\text { COPD: } 18.8 \% \\
\text { Liver disease: I.1\% } \\
\text { Myocardial infarction: } \\
7.4 \%\end{array}$ \\
\hline
\end{tabular}

Breast cancer

\begin{tabular}{|c|c|c|c|c|c|c|}
\hline $\begin{array}{l}\text { Berglund } \\
\text { et } \mathrm{al}^{38}\end{array}$ & $\begin{array}{l}\text { Population-based } \\
\text { cohort study, Sweden }\end{array}$ & $1992-2008$ & 42,646 & BC, all stages & $\mathrm{CCl}$ & $\begin{array}{l}\text { Total: } 13 \% \\
\mathrm{CCl} \text { I: } 7 \% \\
\mathrm{CCl} \geq 2: 6 \%\end{array}$ \\
\hline
\end{tabular}




\begin{tabular}{|c|c|c|}
\hline End points assessed & Results related to comorbidity & Main conclusion \\
\hline $\begin{array}{l}\text { Referral to medical oncologist } \\
\text { within } 6 \text { months of diagnosis } \\
\text { Receipt of chemotherapy }\end{array}$ & 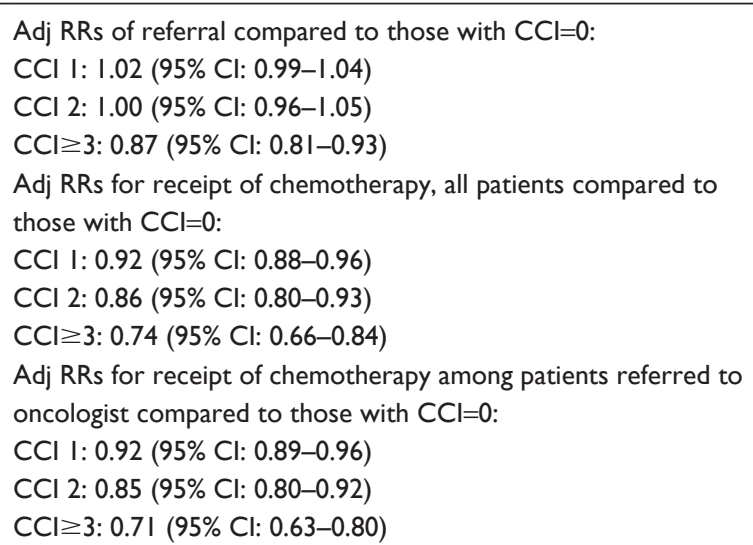 & $\begin{array}{l}\text { Comorbidity decreases the likelihood of } \\
\text { receiving chemotherapy, but does not affect } \\
\text { referral to a medical oncologist. }\end{array}$ \\
\hline $\begin{array}{l}5-7 \text { months of fluorouracil- } \\
\text { based adjuvant chemotherapy }\end{array}$ & $\begin{array}{l}\text { Adj ORs for } 5-7 \text { months' treatment compared to those } \\
\text { with } \mathrm{CCl}=0 \text { : } \\
\mathrm{CCl} \text { I: } 0.75(95 \% \mathrm{Cl}: 0.60-0.97) \\
\mathrm{CCl}>\text { I: } 0.62(95 \% \mathrm{Cl}: 0.46-0.84)\end{array}$ & $\begin{array}{l}\text { Patients with comorbidity are less likely to } \\
\text { complete } 5-7 \text { months of fluorouracil-based } \\
\text { chemotherapy. }\end{array}$ \\
\hline $\begin{array}{l}\text { Initiation of chemotherapy } \\
\text { Completion of chemotherapy } \\
\text { if initiated } \\
\text { Hospitalization attributable to } \\
\text { chemotherapy among treated } \\
\text { patients }\end{array}$ & 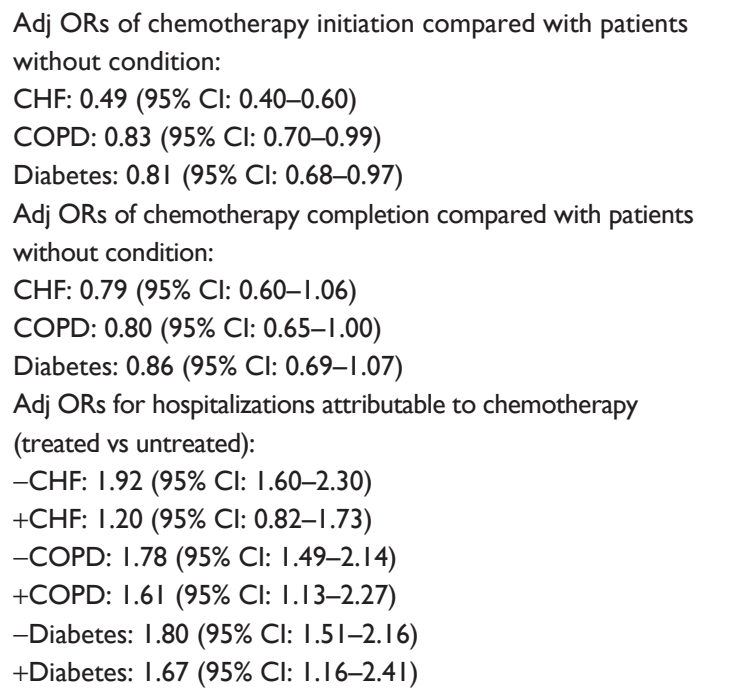 & $\begin{array}{l}\text { Patients with CHF, COPD, and diabetes } \\
\text { are less likely to receive and complete } \\
\text { chemotherapy. However, the odds of } \\
\text { hospitalizations attributable to chemotherapy } \\
\text { are higher among patients without CHF, } \\
\text { COPD, and diabetes. }\end{array}$ \\
\hline Treatment received & $\begin{array}{l}\text { Adj ORs compared to those with CCl=0: } \\
\text { No surgery } \\
\mathrm{CCl} \text { I: I.88 (95\% Cl: I.65-2.I4) } \\
\mathrm{CCl} \geq 2: 3.0 \text { I (95\% Cl: } 2.67-3.4 \mathrm{I}) \\
\text { Mastectomy } \\
\mathrm{CCl} \text { I: I.0I (95\% Cl: } 0.93-\mathrm{I} .09) \\
\mathrm{CCl} \geq 2: 0.97(95 \% \mathrm{Cl}: 0.89-\mathrm{I} .05) \\
\mathrm{BCS} \\
\mathrm{CCl} \text { I: } 0.8 \mathrm{I}(95 \% \mathrm{Cl}: 0.74-0.88) \\
\mathrm{CCl} \geq 2: 0.63(95 \% \mathrm{Cl}: 0.58-0.69) \\
\mathrm{BCS}+\mathrm{RT} \\
\mathrm{CCl} \text { I: } 0.89(95 \% \mathrm{Cl}: 0.78-\mathrm{I} .02) \\
\mathrm{CCl} \geq 2: 0.72(95 \% \mathrm{Cl}: 0.62-0.83) \\
\mathrm{Tamoxifen} \\
\mathrm{CCl} \text { I: } 0.93(95 \% \mathrm{Cl}: 0.84-\mathrm{I} .04) \\
\mathrm{CCl} \geq 2: 0.88(95 \% \mathrm{Cl}: 0.78-0.99)\end{array}$ & $\begin{array}{l}\text { Patients with comorbidity are less likely } \\
\text { to undergo surgery and to receive BCS, } \\
\text { chemotherapy, and tamoxifen. }\end{array}$ \\
\hline
\end{tabular}


Table I (Continued)

\begin{tabular}{|c|c|c|c|c|c|c|}
\hline Author & Design, country & $\begin{array}{l}\text { Study } \\
\text { duration }\end{array}$ & $\begin{array}{l}\text { No of } \\
\text { patients }\end{array}$ & Study population & $\begin{array}{l}\text { Comorbidity } \\
\text { assessed }\end{array}$ & $\%$ with comorbidity \\
\hline
\end{tabular}

Land et al ${ }^{6}$

Population-based cohort study,

Denmark

O'Connor

et al ${ }^{100}$

Cohort study, USA

1997-2004

204

|990-2008 62,59|

BC

$\mathrm{CCl}$

Overall: $19.7 \%$

CCI I: $10.2 \%$

$\mathrm{CCl} 2: 6.0 \%$

$\mathrm{CCl} \geq 3: 3.5 \%$

$\geq 65$ years, stage

I-III

$\mathrm{CCl}$

$\mathrm{BMI}$

N/A

\begin{tabular}{|c|c|c|c|c|c|c|}
\hline $\begin{array}{l}\text { Punglia } \\
\text { et al }\left.\right|^{106}\end{array}$ & Cohort study, USA & $|99|-2002$ & 18,050 & $\begin{array}{l}\geq 65 \text { years who } \\
\text { received } B C S \text { and } \\
\text { RT, stage } 0-I I \\
\text { breast cancer }\end{array}$ & $\mathrm{CCl}$ & $\begin{array}{l}\text { Overall: } 23.3 \% \\
C C I \text { I: } 17.4 \% \\
C C I \text { 2: } 3.2 \% \\
C C I \geq 3: 2.6 \%\end{array}$ \\
\hline Gold et al ${ }^{104}$ & Cohort study, USA & $|99|-1999$ & 7,791 & $\begin{array}{l}\text { DCIS + stage I } \\
\text { breast cancer }\end{array}$ & $\begin{array}{l}\text { Klabunde inpatient and } \\
\text { outpatient comorbidity } \\
\text { indices }^{149}\end{array}$ & N/A \\
\hline Yood et al ${ }^{139}$ & Cohort study, USA & $1990-1994$ & I,837 & $\begin{array}{l}\geq 65 \text { years, stage } \\
\text { I-II }\end{array}$ & $\mathrm{CCl}$ & $\begin{array}{l}\text { Overall: } 31.8 \% \\
\mathrm{CCI} I: 27.1 \% \\
\mathrm{CCl} \geq 2: 4.7 \%\end{array}$ \\
\hline $\begin{array}{l}\text { Giordano } \\
\text { et } \mathrm{al}^{140}\end{array}$ & Cohort study, USA & $|99|-1999$ & 41,390 & $\begin{array}{l}\geq 65 \text { years, stage } \\
\text { I-III }\end{array}$ & $\mathrm{CCl}$ & $\begin{array}{l}\text { Overall: } 35.0 \% \\
\mathrm{CCI} I: 24.6 \% \\
\mathrm{CCl} \geq 2: 10.4 \%\end{array}$ \\
\hline Buist et al ${ }^{|4|}$ & Cohort study, USA & $1990-1994$ & 897 & $\begin{array}{l}\geq 65 \text { years, stage } \\
\text { I-IIB }\end{array}$ & $\begin{array}{l}\mathrm{BMI} \\
\mathrm{CCl} \\
+ \text { list of individual } \\
\text { diseases }\end{array}$ & $\begin{array}{l}64 \% \text { were overweight } \\
\text { or obese }\end{array}$ \\
\hline
\end{tabular}




\begin{tabular}{|c|c|c|}
\hline End points assessed & Results related to comorbidity & Main conclusion \\
\hline & $\begin{array}{l}\text { Aromatase inhibitor } \\
\mathrm{CCl} \text { I: I.I7 (95\% Cl: 0.99-I.39) } \\
\mathrm{CCl} \geq 2 \text { : I.34 (95\% Cl: I.I2-I.60) } \\
\text { Chemotherapy } \\
\mathrm{CCl} \text { I: } 0.78 \text { ( } 95 \% \mathrm{Cl}: 0.68-0.89) \\
\mathrm{CCl} \geq 2: 0.76(95 \% \mathrm{Cl}: 0.66-0.87)\end{array}$ & \\
\hline $\begin{array}{l}\text { Treatment received } \\
\text { Mortality }\end{array}$ & $\begin{array}{l}\text { Mastectomy } 63 \% \text { in } \mathrm{CCl} 0 \text { vs } 63 \% \text { in } \mathrm{CCl} \geq 3 \\
\text { Lumpectomy } 33 \% \text { in } \mathrm{CCl} 0 \text { vs } 22 \% \text { in } \mathrm{CCl} \geq 3 \\
\text { Biopsy alone } 4 \% \text { in } \mathrm{CCl} 0 \text { vs } 15 \% \text { in } \mathrm{CCl} \geq 3 \\
\text { Adjuvant therapy } \\
\text { None: } 25 \% \text { in } \mathrm{CCl} 0 \text { vs } \mathrm{I} 3 \% \text { in } \mathrm{CCl} \geq 3 \\
\text { Endocrine therapy } 26 \% \text { in } \mathrm{CCl} 0 \text { vs } 23 \% \text { in } \mathrm{CCl} \geq 3 \\
\text { Chemotherapy } 15 \% \text { in } \mathrm{CCl} 0 \text { vs } 6 \% \text { in } \mathrm{CCl} \geq 3 \\
\text { Chemotherapy + endocrine therapy } 10 \% \text { in } \mathrm{CCl} 0 \text { vs } 2 \% \text { in } \mathrm{CCl} \geq 3 \\
\text { Unknown } 24 \% \text { in } \mathrm{CCl} 0 \text { vs } 56 \% \text { in } \mathrm{CCl} \geq 3 \\
\mathrm{CCl} \geq 3 \text { women had fewer lymph nodes removed }\end{array}$ & $\begin{array}{l}\text { Patients with comorbidity are more likely } \\
\text { to receive BCS without radiation therapy, } \\
\text { to undergo only biopsy, and to receive less } \\
\text { adjuvant therapy. }\end{array}$ \\
\hline $\begin{array}{l}\text { Problematic chemotherapy } \\
\text { delivery }\end{array}$ & 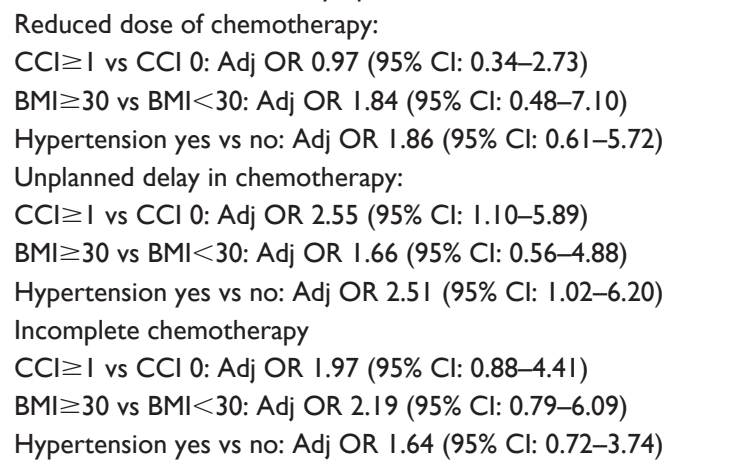 & $\begin{array}{l}\text { Patients with comorbidity and obesity are } \\
\text { more likely to receive a reduced dose of } \\
\text { chemotherapy, to experience unplanned } \\
\text { delays in treatment initiation, and to } \\
\text { receive less than a complete course of } \\
\text { chemotherapy. }\end{array}$ \\
\hline Interval to RT of over 6 weeks & $\begin{array}{l}\text { Adj ORs compared to those with CCl=0: } \\
\mathrm{CCl} \text { I: Adj OR I.I I (95\% Cl: I.02-I.2I) } \\
\mathrm{CCl} 2 \text { : Adj OR I.I2 (95\% Cl: } 0.93-1.33) \\
\mathrm{CCl} \geq 3: \text { Adj OR } 0.89(95 \% \mathrm{Cl}: 0.72-1.09)\end{array}$ & $\begin{array}{l}\text { Patients with low or moderate but not } \\
\text { severe comorbidity are more likely to } \\
\text { experience delays in RT initiation. }\end{array}$ \\
\hline Delay and noncompletion of RT & $\begin{array}{l}\text { Adj OR for delayed RT among DCIS patients with comorbidity: } \\
\text { I.88 ( } 95 \% \mathrm{Cl} \text { : I.05-3.35) compared with patients without } \\
\text { comorbidity. } \\
\text { Odds for delayed RT among stage I BC patients with } \\
\text { comorbidity: I.I } 4 \text { ( } 95 \% \mathrm{Cl} \text { : } 0.89-1.48) \text { compared with patients } \\
\text { without comorbidity. } \\
\text { Odds for not completing RT among stage I BC patients with } \\
\text { comorbidity: I. } 28 \text { ( } 95 \% \mathrm{Cl}: 0.82-1.99) \text { compared with patients } \\
\text { without comorbidity }\end{array}$ & $\begin{array}{l}\text { Patients with comorbidity are more likely to } \\
\text { receive RT after a delay and to receive less } \\
\text { than a complete course of RT. }\end{array}$ \\
\hline Treatment received & $\begin{array}{l}\mathrm{CCl} 0: 10 \% \mathrm{BSC}, 37 \% \mathrm{BSC}+\mathrm{RT}, 53 \% \text { mastectomy } \\
\mathrm{CCl} \mathrm{I}: 17 \% \mathrm{BSC}, 31 \% \mathrm{BSC}+\mathrm{RT}, 52 \% \text { mastectomy } \\
\mathrm{CCl} \geq 2: 18 \% \mathrm{BSC}, 25 \% \mathrm{BSC}+\mathrm{RT}, 56 \% \text { mastectomy }\end{array}$ & $\begin{array}{l}\text { Patients with comorbidity are more likely to } \\
\text { receive only BCS without RT. }\end{array}$ \\
\hline Use of chemotherapy & $\begin{array}{l}\text { Adj ORs compared to those with } \mathrm{CCl}=0 \text { : } \\
\mathrm{CCl} \text { I: Adj OR } 0.76 \text { ( } 95 \% \mathrm{Cl}: 0.68-0.84) \\
\mathrm{CCl} \geq 2 \text { : Adj OR } 0.49 \text { ( } 95 \% \mathrm{Cl}: 0.4 \mathrm{I}-5.57)\end{array}$ & $\begin{array}{l}\text { Patients with comorbidity are less likely to } \\
\text { receive chemotherapy. }\end{array}$ \\
\hline Treatment received & 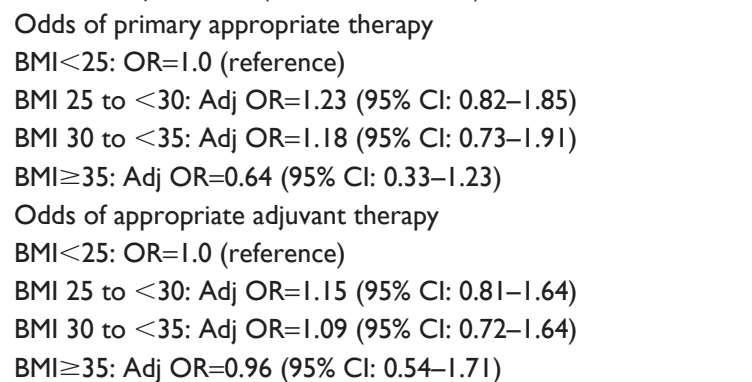 & $\begin{array}{l}\text { Receipt of appropriate primary treatment } \\
\text { and adjuvant therapy is not associated } \\
\text { with BMI. }\end{array}$ \\
\hline
\end{tabular}


Table I (Continued)

\begin{tabular}{|c|c|c|c|c|c|c|}
\hline Author & Design, country & $\begin{array}{l}\text { Study } \\
\text { duration }\end{array}$ & $\begin{array}{l}\text { No of } \\
\text { patients }\end{array}$ & Study population & $\begin{array}{l}\text { Comorbidity } \\
\text { assessed }\end{array}$ & $\%$ with \\
\hline $\begin{array}{l}\text { McCarthy } \\
\text { et } \mathrm{al}^{142}\end{array}$ & Cohort study, USA & |988-1999 & $100,3 \mid 1$ & $\begin{array}{l}2 \text { I-62 years, } \\
\text { stages I-IIIA }\end{array}$ & Disability & $2.7 \%$ \\
\hline $\begin{array}{l}\text { Houterman } \\
\text { et } \mathrm{al}^{32}\end{array}$ & $\begin{array}{l}\text { Cohort study, The } \\
\text { Netherlands }\end{array}$ & $1995-1999$ & 527 & $\begin{array}{l}\geq 40 \text { years, all } \\
\text { stages }\end{array}$ & $\begin{array}{l}\text { List of individual } \\
\text { diseases categorized as } \\
\text { low impact, moderate } \\
\text { impact, high impact }\end{array}$ & N/A \\
\hline
\end{tabular}

\section{Lung cancer}

Wang et $\mathrm{al}^{143}$

$$
\text { Population-based }
$$

cohort study, USA
2003-2008 20,5II

NSCLC, veterans

$\geq 65$ years, all

stages
$\mathrm{CCl}$

Overall: $81.2 \%$

CCI I-3: $62.7 \%$

$\mathrm{CCl} \geq 4: 18.4 \%$ $\begin{array}{ll}\text { Lüchtenborg } & \text { Nationwide cohort } \\ \text { et al } & \text { study, Denmark }\end{array}$

Rueth et al ${ }^{90}$
NSCLC, 66-80

years undergoing

lobectomy, stage I
$\mathrm{CCl}$

Overall: $26.4 \%$

CCI I: $13.9 \%$

$\mathrm{CCl} \geq 2: 12.5 \%$ $\begin{array}{ll}\text { Booth et al } & \text { Cohort study, } \\ \text { Canada }\end{array}$
2004-2006

3,354
NSCLC, all stages
$\mathrm{CCl}$

Overall: $26.7 \%$

CCl I-2: $22.8 \%$

$\mathrm{CCl} \geq 3: 4.9 \%$ 


\begin{tabular}{ll}
\hline End points assessed & Results related to comorbidity \\
\hline Odds of appropriate hormonal therapy \\
$\mathrm{BMI}<25: \mathrm{OR}=\mathrm{I} .0$ (reference) \\
$\mathrm{BMI} 25$ to $<30:$ Adj $\mathrm{OR}=\mathrm{I} . \mathrm{I3}(95 \% \mathrm{Cl}: 0.76-1.67)$ \\
$\mathrm{BMI} 30$ to $<35:$ Adj OR=I.09 $(95 \% \mathrm{Cl}: 0.69-1.73)$ \\
$\mathrm{BMI} \geq 35:$ Adj $\mathrm{OR}=\mathrm{I} . \mathrm{I} 2(95 \% \mathrm{Cl}: 0.58-2.16)$
\end{tabular}

Treatment received

Treatment received Number of complications

Guideline-recommended treatment

Odds of surgical resection I-year mortality among patients who underwent resection

Postoperative complications

Dose modification of adjuvant chemotherapy
Disabled were less likely than other women to receive BCS (Adj RR 0.80, 95\% Cl: 0.76-0.84), RT (Adj RR 0.83, 95\% Cl: $0.77-0.90$ ), and axillary lymph node dissection (Adj RR 0.8I, 95\% Cl: 0.74-0.90)

$<70$ years: treatment was not influenced by severity

of comorbidity

$\geq 70$ years: patients with high comorbidity slightly more often received surgery + systemic therapy, and less surgery alone or surgery + RT (no estimates provided). $35 \%$ without comorbidity received $\mathrm{BCS}+$ axillary dissection vs $23 \%$ among women with high severity of comorbidity. No patients without comorbidity had two or more complications vs $6 \%$ among patients with low severity comorbidity, $10 \%$ among those with moderate severity comorbidity, and $1 \%$ among those with high severity

Adj rates of guideline recommended treatment

Local disease:

$\mathrm{CCl} 0: 60 \%$

CCI I-3: $48.9 \%$

$\mathrm{CCl} \geq 4: 45.7 \%$

Regional disease:

CCI 0: $38.7 \%$

CCI I-3: $33.7 \%$

$\mathrm{CCl} \geq 4: 27.8 \%$

Metastatic disease:

CCl 0: $27.6 \%$

CCI I-3: $26.9 \%$

$\mathrm{CCl} \geq 4: 22.4 \%$

Adj ORs of surgical resection compared to those with $\mathrm{CCl}=0$ : CCl I-2: 0.87 (95\% Cl: 0.80-0.95)

$\mathrm{CCl} \geq 3: 0.75$ (95\% Cl: 0.67-0.85)

Adj HRs of I-year mortality compared to those with $\mathrm{CCl}=0$ :

CCI I: I. 14 (95\% Cl: 0.88-I.48)

CCl 2: I. 12 (95\% Cl: $0.8 \mathrm{I}-\mathrm{I} .6 \mathrm{I})$

$\mathrm{CCl} \geq 3: 1.57(95 \% \mathrm{Cl}: 1.17-2.12)$

Adj ORs of complications compared to those with $\mathrm{CCl} 0$ :

Any complications:

CCI I: I.38 (95\% Cl: I. I5-I.66)

$\mathrm{CCl} \geq 2: 1.83(95 \% \mathrm{Cl}:$ I.50-2.23)

Pulmonary complications:

CCI I: I.32 (95\% Cl: I. I0-I.59)

$\mathrm{CCl} \geq 2:$ I.5 I (95\% Cl: I.25-I.83)

Cardiac complications:

CCI I: $1.36(95 \% \mathrm{Cl}:$ I.I I-I.66)

$\mathrm{CCl} \geq 2:$ I.57 (95\% Cl: I.28-I.93)

Non-cardiopulmonary complications:

CCI I: I. 19 (95\% Cl: 0.95-I.52)

$\mathrm{CCl} \geq 2:$ I.29 (95\% Cl: $1.02-1.65)$

Adj ORs compared to those with $\mathrm{CCl} 0$ :

CCl I-2: 1.48 (95\% Cl: 0.94-2.34)

$\mathrm{CCl} \geq 3:$ I.27 (95\% Cl: $0.35-4.58)$

\section{Main conclusion}

Disabled patients are less likely to receive BCS, RT, and axillary lymph node dissection.

The association between comorbidity and treatment varies with age. Elderly patients with comorbidity receive less extensive treatment and more often have complications.

Patients with comorbidity are less likely to receive guideline-recommended treatment.

Patients with comorbidity are less likely to undergo surgical resection.

The odds of any complication are increased among patients with comorbidity who undergo surgery.

Patients with comorbidity are more likely to have their chemotherapy dose modified. 
Table I (Continued)

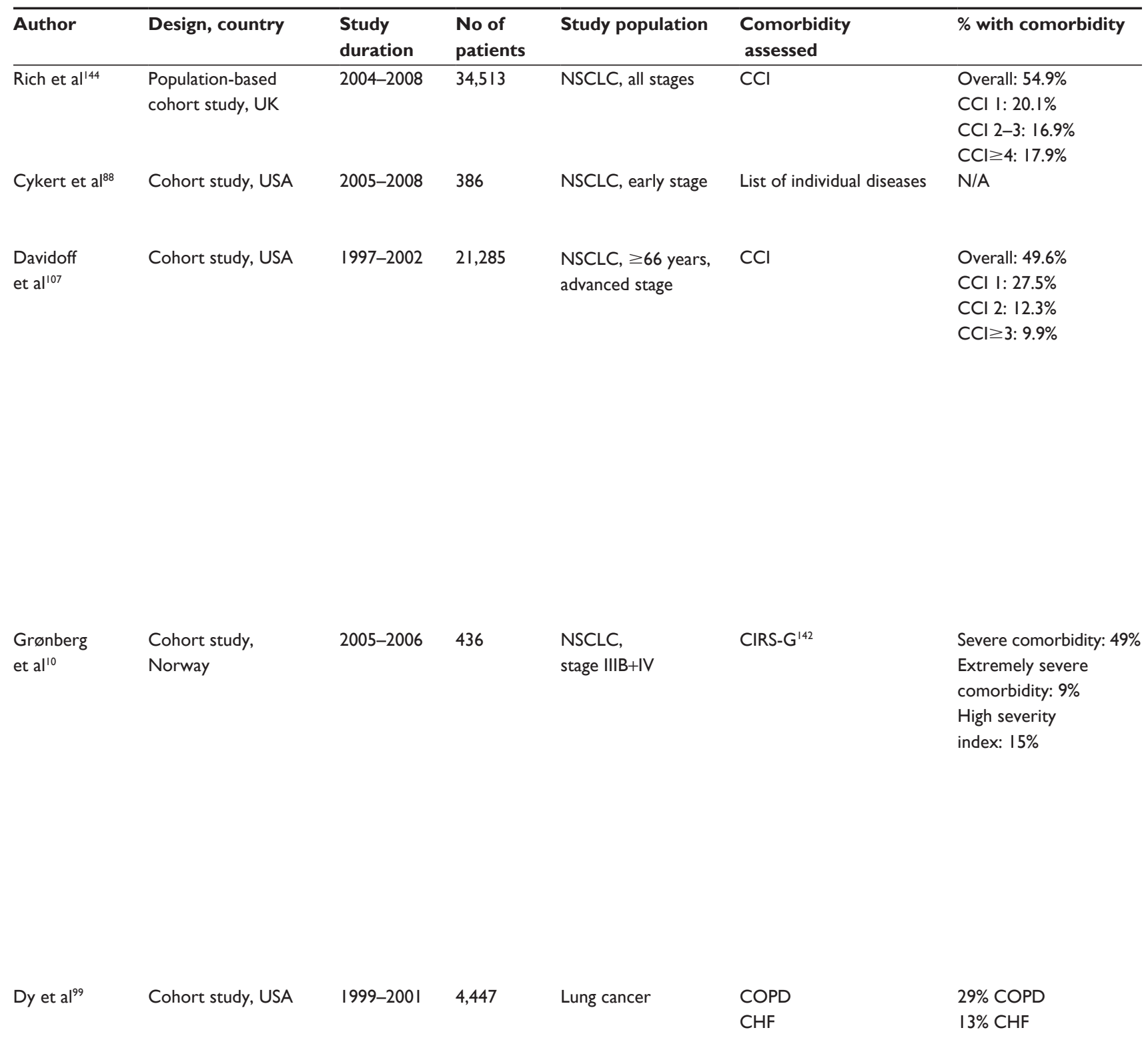

Abbreviations: ASA, American Society of Anesthesiologists; adj, adjusted; BC, breast cancer; BCS, breast-conserving surgery; BMI, body mass index; CC, colon cancer; $\mathrm{CCl}$, Charlson Comorbidity Index; CHF, chronic heart failure; CIRS-G, Cumulative Illness Rating Scale for Geriatrice; COPD, chronic obstructive pulmonary disease; CRC, colorectal cancer; DCIS, ductal carcinoma in situ; DVT, deep venous thrombosis; HR, hazard ratio; N/A, not available; NSCLC, non-small-cell lung cancer; OR, odds ratio; $R R$, relative risk; $R T$, radiation therapy.

For patients with breast cancer, the 5-year HR for CCI score $\geq 3$ vs CCI score of 0 was 0.48 (95\% CI: $0.21-1.07$ ), and for patients with colorectal cancer, the 5-year HR for CCI score $\geq 3$ vs CCI score of 0 was 1.00 (95\% CI: $0.76-$ 1.33). In contrast, Land et $\mathrm{al}^{6}$ recently found an association between comorbidity and cancer-specific mortality in women with breast cancer (HR for CCI score $\geq 3$ vs CCI score of $0=1.79$ [95\% CI: 1.66-1.93]). Median follow-up time in the study was 8.2 years. Berglund et $\mathrm{al}^{38}$ found a similar association in women with early-stage breast cancer 


\begin{tabular}{|c|c|c|}
\hline End points assessed & Results related to comorbidity & Main conclusion \\
\hline Odds of having surgery & $\begin{array}{l}\text { Adj ORs compared to those with CCl 0: } \\
\mathrm{CCl} \text { I: } 0.95 \text { (95\% Cl: } 0.86-1.04) \\
\mathrm{CCl} 2-3: 0.89 \text { (95\% Cl: } 0.80-0.99) \\
\mathrm{CCl} \geq 4: 0.67(95 \% \mathrm{Cl}: 0.56-0.80)\end{array}$ & $\begin{array}{l}\text { Patients with comorbidity are less likely to } \\
\text { undergo surgical resection. }\end{array}$ \\
\hline $\begin{array}{l}\text { Surgery within } 4 \text { months of } \\
\text { diagnosis }\end{array}$ & $\begin{array}{l}\text { Adj OR of surgery compared to those with }<2 \text { comorbidities: } \\
\geq 2 \text { comorbidities: } 0.42 \text { ( } 95 \% \mathrm{Cl}: 0.22-0.84)\end{array}$ & $\begin{array}{l}\text { Patients with comorbidity are less likely } \\
\text { to undergo surgery within } 4 \text { months of } \\
\text { diagnosis. }\end{array}$ \\
\hline $\begin{array}{l}\text { Receipt of }(I) \text { any chemotherapy } \\
\text { within } 90 \text { days and }(2) \text { single } \\
\text { agent, relative to platinum-based } \\
\text { doublet therapy } \\
\text { 2-year survival benefit } \\
\text { associated with treatment }\end{array}$ & 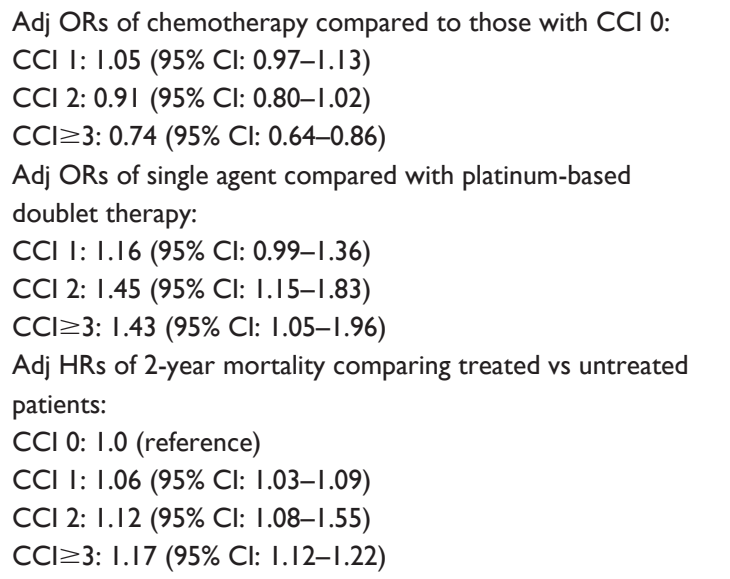 & $\begin{array}{l}\text { Patients with comorbidity are less likely to } \\
\text { receive chemotherapy, including platinum- } \\
\text { based doublet therapy. }\end{array}$ \\
\hline $\begin{array}{l}\text { Receipt of chemotherapy } \\
\text { Receipt of toxicity }\end{array}$ & $\begin{array}{l}\text { Patients with severe comorbidity vs patients without severe } \\
\text { comorbidity: } \\
\text { Mean number of chemotherapy cycles: } 3.2 \text { vs } 3.5 \\
\text { Completed all four cycles: } 65 \% \text { vs } 73 \% \\
\text { Completed cycles without delay: } 46 \% \text { vs } 59 \% \\
\text { Dose reductions: } 29 \% \text { vs } 35 \% \\
\text { Second line systemic therapy: } 27 \% \text { vs } 26 \% \\
\text { RT: } 35 \% \text { vs } 48 \% \\
\text { Toxicity: } \\
\text { Grade } 3-4 \text { thrombocytopenia: } 46 \% \text { vs } 36 \% \\
\text { Thrombocytopenic bleedings: } 3 \% \text { vs } 4 \% \\
\text { Grade } 3-4 \text { neutropenia: } 48 \% \text { vs } 42 \% \\
\text { Neutropenic fevers: I } 2 \% \text { vs } 5 \% \\
\text { Death from neutropenic infection: } 3 \% \text { vs } 0 \%\end{array}$ & $\begin{array}{l}\text { Patients with comorbidity are less likely } \\
\text { to complete all cycles of chemotherapy } \\
\text { and have slightly more dose reductions. } \\
\text { Thrombocytopenia and neutropenia are } \\
\text { slightly more frequent among patients with } \\
\text { comorbidity. }\end{array}$ \\
\hline $\begin{array}{l}\text { Receipt of surgery, } \\
\text { chemotherapy, and RT }\end{array}$ & $\begin{array}{l}\text { Adj ORs compared to patients with neither COPD nor CHF: } \\
\text { OR of surgery to resect lung cancer } \\
\text { COPD: } 0.66 \text { ( } 95 \% \mathrm{Cl}: 0.52-0.83) \\
\text { COPD: } 0.28 \text { ( } 95 \% \mathrm{Cl}: 0.15-0.50) \\
\text { OR of receiving adjuvant chemotherapy } \\
\text { COPD: } 0.74 \text { (95\% Cl: } 0.62-0.89) \\
\text { COPD: } 0.66 \text { (95\% Cl: } 0.46-0.96) \\
\text { OR of RT } \\
\text { COPD: } 1.02 \text { (95\% Cl: } 0.86-0.89) \\
\text { COPD: } 0.91 \text { (95\% Cl: } 0.66-1.27)\end{array}$ & $\begin{array}{l}\text { Patients with COPD or CHF are less likely } \\
\text { to undergo surgery and more likely to } \\
\text { receive chemotherapy but not RT. }\end{array}$ \\
\hline
\end{tabular}

(stage I: HR for CCI score $\geq 2$ vs CCI score of $0=1.47$ [95\% CI: 1.11-1.94]), but not in women with more advanced cancer (stage IIB: HR for CCI score $\geq 2$ vs CCI score of $0=0.83$ [95\% CI: 0.63-1.10]). Several other studies have found an association between increasing levels of comorbidity and higher cancer-related mortality among patients with colon, breast, or lung cancer. ${ }^{8,9,25,39-41}$ However, there is considerable uncertainty in defining whether death was due to the cancer or to other causes (including comorbidity), and the validity of cause-of-death data may be questioned. ${ }^{42-44}$ 


\section{Effect of comorbidity on survival}

Comorbidity can affect cancer survival through its impact on such factors as cancer detection, treatment, and adherence. ${ }^{45}$ In the following sections, we focus on the potential role of comorbidity on different points from cancer detection through diagnosis and treatment.

\section{Impact of comorbidity on cancer morphology, histology, differentiation, and proliferation status}

It is plausible that comorbidity is associated with differences in morphology, histology, differentiation, and proliferation status. Cancer risk is elevated in patients with obesity; in patients with diabetes and resulting insulin resistance and chronic hyperinsulinemia; ${ }^{46-49}$ and in patients with inherited, acquired (eg, from HIV/AIDS), or drug-induced (eg, from treatment with steroids or biologics) immunosuppression. . $^{50,51}$ Some of these risk factors also may be associated with rate of cancer growth and cancer grade/differentiation and thus with prognosis. Conversely, drugs such as nonsteroidal antiinflammatory agents, ${ }^{52,53}$ aspirin, ${ }^{54,55}$ statins, ${ }^{56}$ and long-term antibiotics used to treat comorbidity-associated infections ${ }^{57}$ may decrease cancer incidence, ${ }^{52-55}$ progression, ${ }^{53,56}$ and risk of recurrence and improve cancer prognosis. ${ }^{58-61}$

As shown in Table 2, the proportion of squamous cell carcinoma in lung cancer patients with comorbidity has been found to be $6 \%-11 \%$ higher than in patients without comorbidity. ${ }^{10,11}$ Chlebowski et al ${ }^{62}$ found a slightly higher proportion of ductal breast cancer (69\% vs $65 \%)$ and a slightly lower proportion of estrogen-receptor-positive breast cancer ( $74 \%$ vs $78 \%$ ) and progesterone-receptorpositive breast cancer (61\% vs $64 \%$ ) among diabetic compared with nondiabetic breast cancer patients (Table 2). Kaplan et $a l^{63}$ also found a higher incidence of ductal breast cancer among diabetics compared with nondiabetics (89\% vs $82 \%)$. In contrast, Land et $\mathrm{al}^{6}$ found no differences in histology or receptor status according to level of comorbidity. However, few studies provided data on tumor biology by comorbidity level.

\section{Comorbidity and other patient characteristics}

Age is closely related to comorbidity and is also a strong predictor of mortality in cancer patients. Thus, older age could potentially explain the prognostic impact of comorbidity. However, the association between comorbidity and cancer survival persists even after adjusting for age. The association also remains after adjusting for other prognostic factors, such as cancer stage and treatment. ${ }^{64}$ It is also plausible that age may modify the relationship between comorbidity and cancer survival if clinicians tend to focus more on comorbidity in older than in younger patients when deciding on type of cancer treatment. ${ }^{65}$ Sex may also play a role, as several studies have indicated that women with lung cancer have a better prognosis than men with lung cancer. ${ }^{66-68}$ The underlying reasons are debated and remain unresolved. In addition, converging evidence from epidemiological studies conducted in a variety of settings have documented racial and socioeconomic disparities in cancer survival. ${ }^{67-74}$ Multiple factors may contribute to these disparities, but comorbidity seems to play an important role. ${ }^{72-77}$ In a US cohort study of 906 women with breast cancer, Tammemagi et al ${ }^{78}$ found an HR for all-cause mortality of 1.14 (95\% CI: 0.92-1.40) for blacks compared to whites after adjusting for age, tumor stage, estrogen receptor status, surgery, chemotherapy, and radiation therapy. After further adjustment for comorbidity, the HR decreased to 1.02 (95\% CI: 0.83-1.27). The two most important comorbidities explaining the disparities were diabetes and hypertension. ${ }^{78} \mathrm{~A}$ Danish cohort study conducted by Dalton et $\mathrm{al}^{79}$ found an interaction between income and comorbidity, resulting in $15 \%$ lower survival within 10 years after primary surgery for early-stage breast cancer among women of low socioeconomic status with comorbid conditions ( $\sim 65 \%)$ compared to more affluent women with similar comorbid conditions $(\sim 80 \%)$. This suggests a differential effect of comorbidity on risk of dying of early-stage breast cancer by socioeconomic group. ${ }^{75}$

\section{Impact of comorbidity on stage at diagnosis}

It is often argued that comorbidities may be associated with late-stage cancer diagnosis because they may mask early cancer symptoms. Dementia, ${ }^{80,81}$ alcohol consumption, ${ }^{82,83}$ and major depression ${ }^{84}$ have been associated with late-stage diagnosis of colon cancer and breast cancer. However, as shown in Table 3, several studies have found a higher prevalence of comorbidity in patients diagnosed with early-stage lung cancer, breast cancer, and colorectal cancer. Earlier cancer diagnosis in patients with comorbidities is plausible because these patients are more likely to require frequent medical care, and hence to receive closer clinical monitoring, than persons without comorbidities. Nonetheless, the association between comorbidity and earlier diagnosis seems to depend on the specific comorbid condition. Fleming et al ${ }^{85}$ found that women with cardiovascular disease, musculoskeletal disease, gastrointestinal disease, osteoarthritis, and genitourinary disease had a $7 \%-24 \%$ lower risk of being diagnosed with advanced breast cancer (Table 3 ). In contrast, women with diabetes, renal disease, other endocrine 


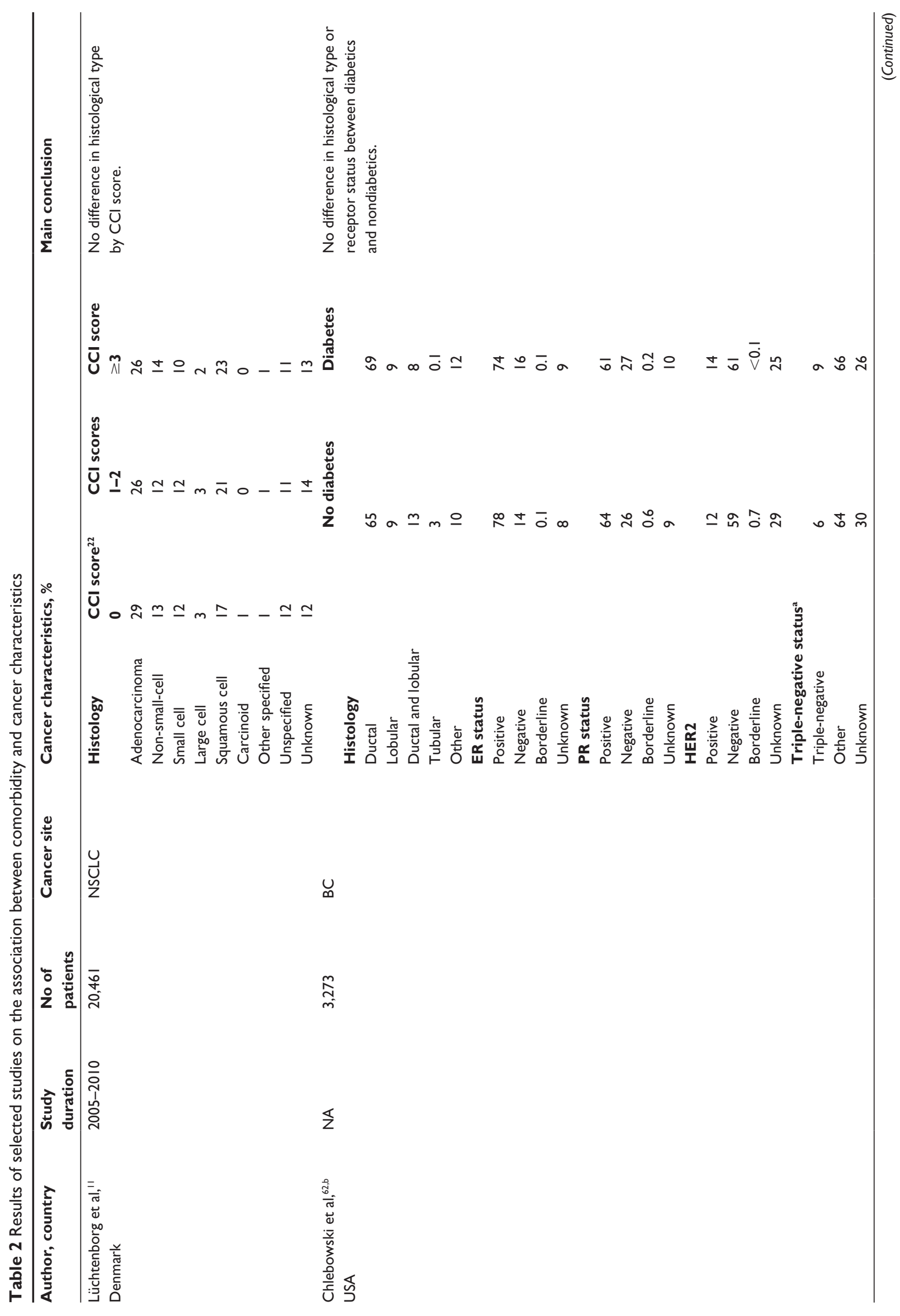




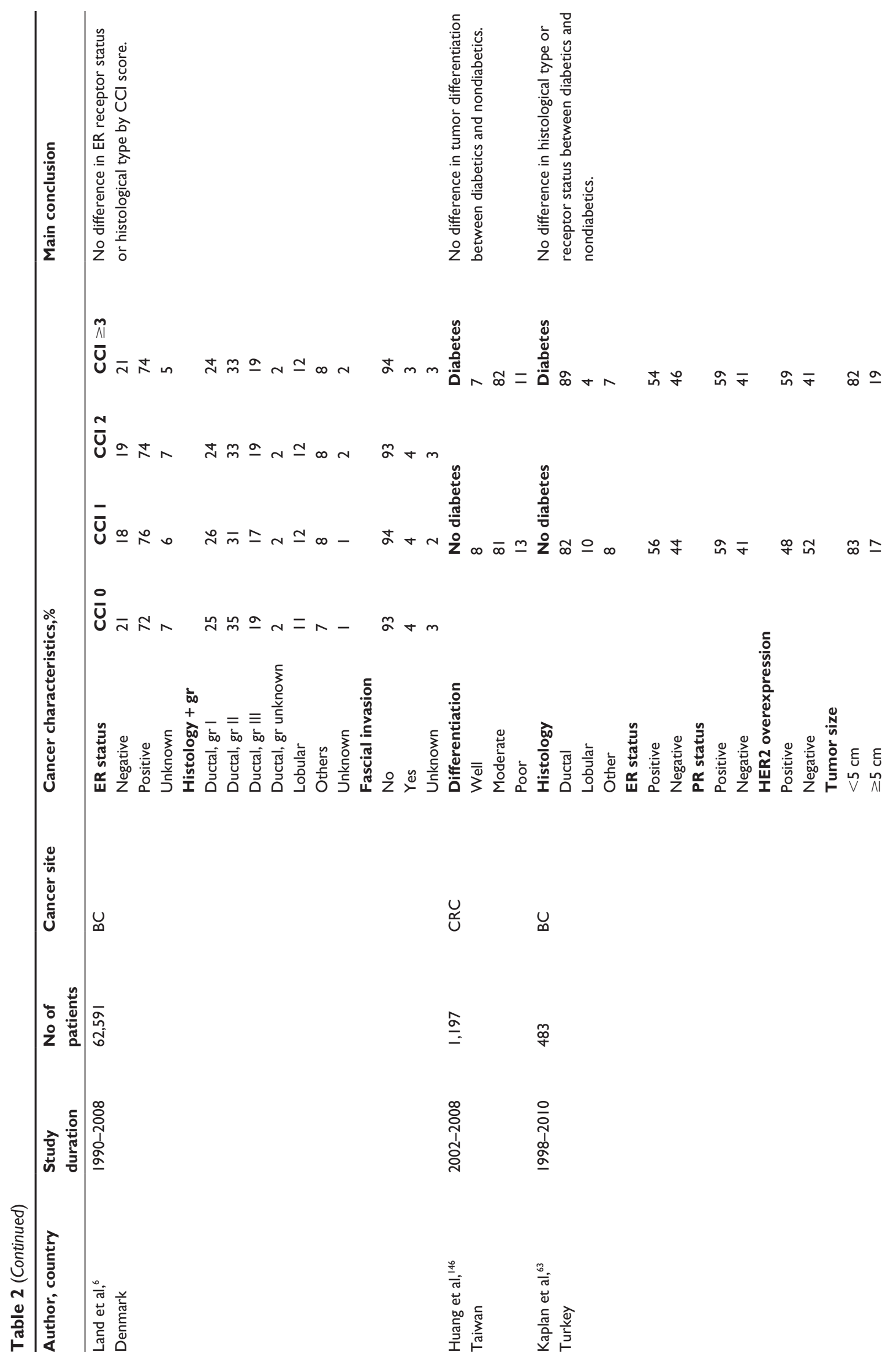


disorders, psychiatric disease, osteoporosis, hematologic disease, obesity, and AIDS had an $11 \%-20 \%$ higher risk of being diagnosed with advanced disease (Table 3). ${ }^{85}$ Similarly, Yasmeen et $\mathrm{al}^{76}$ found that presence of certain comorbidities (eg, arthritis, depression, diabetes, stable coronary artery disease) was associated with higher utilization of screening mammograms and greater likelihood of diagnosis of localized disease (odds ratio [OR] $=0.8,95 \%$ CI: $0.7-0.9$ ), while a group of other comorbidities judged to be more serious (including severe heart failure, cardiac arrhythmias, and endstage pulmonary disease) was associated with less screening mammography and later stage at diagnosis $(\mathrm{OR}=1.3,95 \%$ CI: 1.2-1.4) (Table 3). ${ }^{76}$ Studies relating comorbidity to breast cancer screening have had mixed results, showing either increased or decreased risk of late-stage disease according to comorbidity burden. ${ }^{76,86}$

\section{Impact of comorbidity on choice of treatment}

As shown in Table 1, surgical management steadily declines with increasing comorbidity regardless of cancer site and disease stage. Berglund et $\mathrm{al}^{38}$ found that the OR of no surgery was 1.88 (95\% CI: 1.65-2.14) among breast cancer patients with a CCI score of 1, and 3.01 (95\% CI: 2.67-3.41) among those with a CCI score $\geq 2$, compared with patients without comorbidity. In a population-based cohort study conducted in Northern Denmark, Iversen et $\mathrm{al}^{5}$ found that $83.8 \%$ of colon cancer patients with a CCI score of 0 undergo surgical resection, compared with $77.7 \%$ of patients with CCI scores of 1 or 2 and $63.2 \%$ of patients with a CCI score $\geq 3$. Similarly, other studies have reported $25 \%-58 \%$ lower odds of surgical resection in lung cancer patients with severe comorbidity compared with patients without comorbidity. ${ }^{11,87,88}$ An increased risk of complications among patients with comorbidities who undergo surgical resection for colon cancer (adjusted OR for body mass index of 30-49=1.26 [95\% CI: 1.05-1.49]; for chronic obstructive pulmonary disease $[\mathrm{COPD}]=1.84$ [95\% CI: 1.49-2.27]; and for high ASA physical classification score $=1.65[95 \%$ CI: $1.26-2.16]),{ }^{89}$ for breast cancer ( $6 \%$ with low comorbidity had complications vs $10 \%$ with moderate comorbidity), ${ }^{32}$ and for lung cancer (adjusted OR for a CCI score of $1=1.38$ [95\% CI: 1.15-1.66] and for a CCI score $\geq 2=1.83$ [95\% CI: $1.50-2.23]$ ], ${ }^{90}$ compared with patients without comorbidity (Table 3 ). Other studies have reported 2- to 4-fold higher 30-day postoperative mortality rates in colon cancer patients with comorbidity compared to patients without comorbidities. ${ }^{89,91}$

Patients with comorbidities are less likely to receive any adjuvant chemotherapy, ${ }^{92-99}$ more likely to receive a reduced 


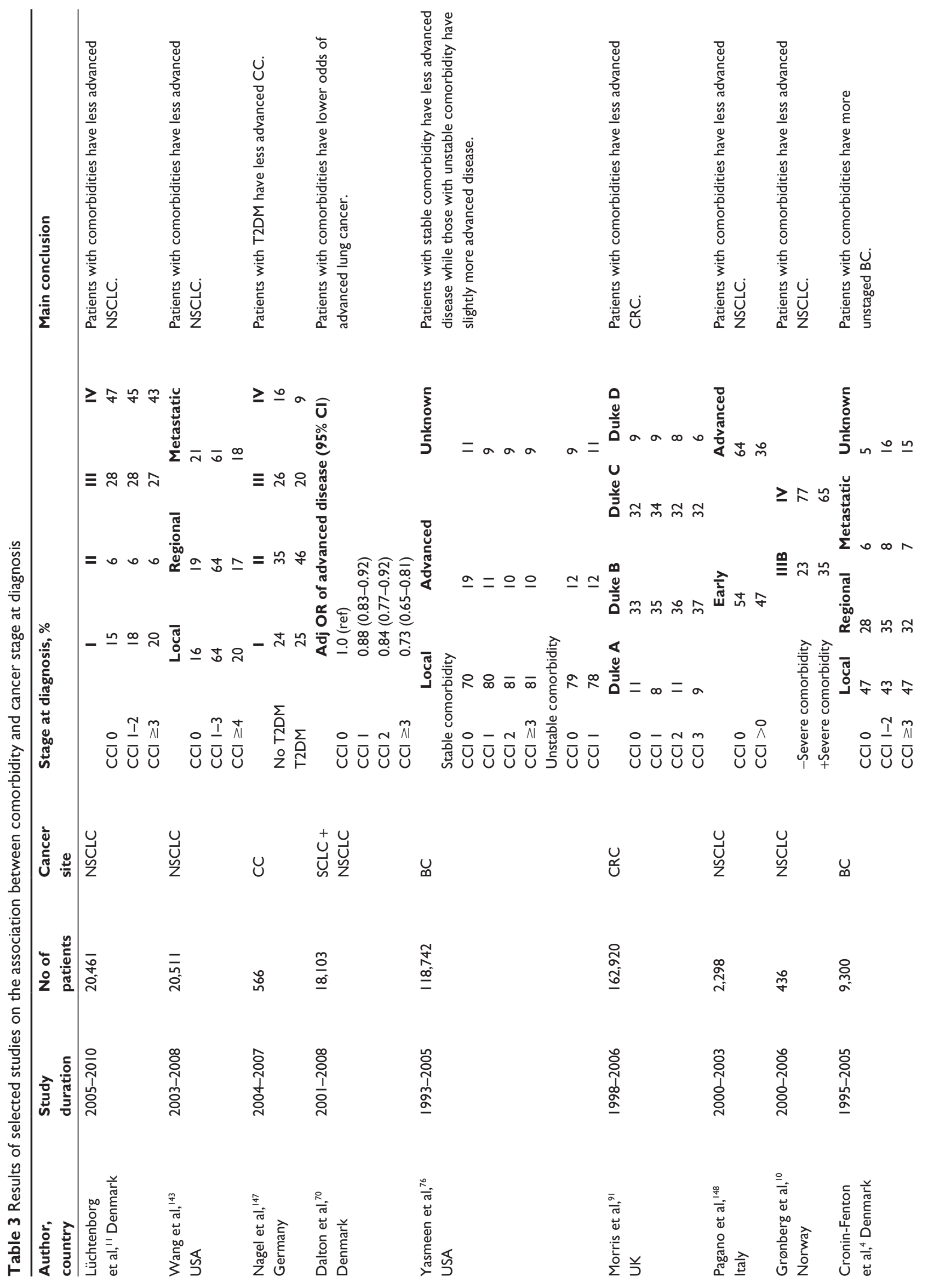




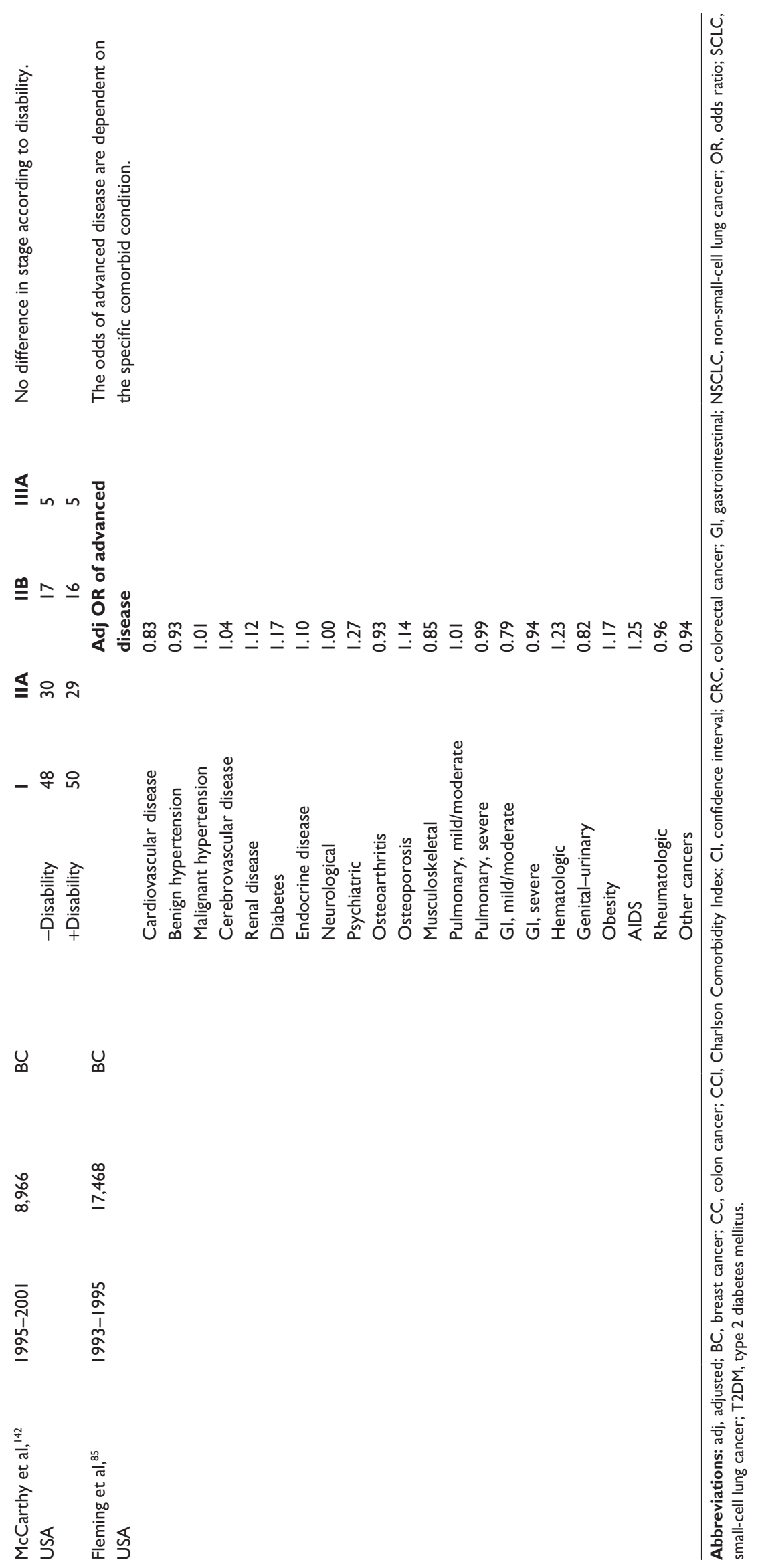


dose, ${ }^{10,100,101}$ and more likely not to complete chemotherapy treatment when initiated ${ }^{101,102-104}$ (Table 1). While some studies report that patients with comorbidity are less likely to be referred to a medical oncologist, ${ }^{95,105}$ a US cohort study of 4,765 colon cancer patients found that patients with comorbidity who underwent resection consulted an oncologist more frequently than patients without comorbidity (adjusted OR for consultation among patients with a CCI score of $1=1.25$ [95\% CI: 0.98-1.59] and among patients with a CCI score $\geq 2=1.61$ [95\% CI: 1.17 to 2.20$]$ ]). ${ }^{94}$ However, in another US study, colon cancer patients with comorbidity were less likely to receive chemotherapy, whether or not they consulted an oncologist (Table 1). ${ }^{95}$ Presence of comorbidity has also been associated with increased time from cancer detection to surgical resection or initiation of chemotherapy or radiotherapy. ${ }^{88,95,104,106,107}$ The reasons for this remain unknown.

There are few data on the impact of comorbidity on risk of complications after chemotherapy and radiation therapy. Grønberg et $\mathrm{al}^{10}$ found that lung cancer patients with severe comorbidity were more likely than lung cancer patients without comorbidity to develop thrombocytopenia (46\% vs $36 \%$ ) or febrile neutropenia ( $12 \%$ vs $5 \%$ ) or to die of neutropenic infection ( $3 \%$ vs $0 . \%$ ) following chemotherapy treatment. Conversely, Gross et al ${ }^{108}$ found that risk of hospitalization attributable to chemotherapy treatment was lower among colon cancer patients with COPD, chronic heart failure, or diabetes, compared with patients without these conditions (Table 1).

Impact of comorbidity on health care-related factors Treatment in specialized medical centers or by a high-volume surgeon has been associated with improved treatment and survival. ${ }^{109-114}$ However, there are very few studies on the prognostic impact of receiving high-volume-cancer-center care and highly specialized treatment in relation to comorbidity. A US study of 211,084 patients with lung, breast, colorectal, and prostate cancer found that patients treated at National Cancer Institute-designated cancer centers had lower mortality than patients treated at volume-matched hospitals across all levels of comorbidity (3-year mortality for specialized vs nonspecialized treatment: adjusted OR for CCI score of $0=0.89$ [95\% CI: $0.85-0.98]$; adjusted OR for CCI score of 1 or $2=0.87$ [95\% CI: $0.80-0.95$ ]; adjusted OR for CCI score $\geq 3=0.83$ [95\% CI: 0.74-1.00]). ${ }^{111}$ Furthermore, while some studies have shown a social gradient in access to specialized cancer care, ${ }^{114,115}$ few studies have examined potential disparities in access to specialized care among patients with comorbidities.
To better understand the observed underutilization of treatment by age and comorbidity, a number of studies have explored physician and patient perspectives regarding the decision to use adjuvant chemotherapy. ${ }^{105,116-119}$ It has been found that $24 \%-70 \%$ of cancer patients with comorbidity are not treated according to guidelines. ${ }^{105,118,120-122}$ In a US national survey of surgeons and medical oncologists caring for patients with colorectal cancer, physicians agreed with guidelines recommending adjuvant chemotherapy for young, otherwise healthy patients with stage III colon cancer, but differed widely on recommendations for patients with comorbid illnesses. ${ }^{119}$ Comorbidity is the most frequent reason for nonreceipt of cancer treatment cited in the medical charts of patients with lung ( $68 \%$ of nontreated patients) and colorectal ( $47 \%$ of nontreated patients) cancer. ${ }^{117,118}$ To some extent, this finding probably reflects concern about toxicity in patients with comorbidity. Among patients with lung cancer, Gironés et $\mathrm{al}^{123}$ recently showed that withholding treatment was associated with factors such as poor health, advanced age, depression, and dementia, but not related to symptoms at diagnosis or cancer stage.

Physicians' motivations and treatment barriers are also influenced by age, race, and education level. Studies have shown that duration of consultations and amount of information provided to patients increases with higher education levels. ${ }^{124-126}$ While patient perceptions and preferences play a role in treatment decisions and outcomes, the treating physician's recommendation has been found to be a major determinant of patients' preferences for chemotherapy. ${ }^{127,128}$ It remains unclear whether patient preferences differ according to level of comorbidity.

\section{Influence of comorbidity on treatment regimen completion}

Patients with comorbidities may be compromised in their ability to comply with treatment regimens or to tolerate their side effects. In a US cohort study of 3,733 colon cancer patients aged $\geq 65$ years with records in the linked SEER-Medicare dataset during 1995-1999, comorbidity was associated with lower odds of completing adjuvant chemotherapy (adjusted ORs were 0.75 [95\% CI: 0.60-0.97] for patients with one comorbidity and 0.62 [95\% CI: 0.46-0.84] for patients with $>1$ comorbidity) compared with patients without comorbidity. ${ }^{129}$ Several other studies have also shown that comorbidity is associated with decreased likelihood of completing chemotherapy treatment among patients with colon, ${ }^{1,102,108}$ breast, ${ }^{100}$ and lung cancer $^{10}$ (Table 1 ). However, none of these studies examined whether failure to complete 
chemotherapy was related to poorer adherence or to level of side effects. Many studies of women with early-stage breast cancer, based on pharmacy, medical, and health insurance data, have reported high rates of discontinuation of adjuvant tamoxifen, ranging from $35 \%-51 \%$ during study periods of 3.5-5 years. ${ }^{130-133}$ Patient refusal reportedly accounts for a third of occurrences of treatment underuse, ${ }^{134}$ and comorbidity has been identified as a predictor of discontinuation and nonadherence to regimens of tamoxifen and aromatase inhibitors. ${ }^{132,133}$ However, a very recent German cohort study of 12,412 women with breast cancer, among whom 7,312 were treated with tamoxifen, demonstrated lower rates of tamoxifen discontinuation among patients with diabetes (adjusted HR $=0.81$ [95\% CI: 0.75-0.86]) and depression (adjusted HR $=0.92$ [95\% CI: $0.87-0.97]) .{ }^{135}$

\section{Methodological considerations}

Several methodological concerns must be considered when evaluating the summary evidence from the studies reviewed above. This review is not a systematic review. A research librarian assisted our searches, but we did not use explicit predefined criteria to select the articles included. Thus, our study selection was subjective and we may have missed relevant papers. The studies included were heterogeneous and included vastly different patient populations (Tables 1-3). Moreover, many were designed as predictive studies and included a wide range of potential prognostic factors besides comorbidity in regression models. Some studies also included variables such as patient performance status (activities of daily living), ${ }^{136}$ which may constitute an intermediate variable in the causal path from comorbidity to cancer survival. Adjusting for patient performance status thus may weaken the prognostic impact of comorbidity. A further challenge in summarizing the effect of comorbidity on cancer survival was inconsistent definitions of comorbidity. Comorbidity was measured in different ways in the studies under review, referring either to one specific disease or aggregation of several diseases using an index. Moreover, indices varied from general comorbidity measures to disease-specific measures. Most studies aggregated comorbidity into a comorbidity index (most frequently the CCI) (Table 1) with little consideration of how specific conditions affected outcomes. Although shown repeatedly to be a valid prognostic predictor, the CCI itself is based on simple assumptions about mortality risk when various conditions co-occur. In addition, most studies collapsed the CCI score of above a certain threshold into a single open-ended category (eg, $0,1-2$, and $\geq 3$ ) to improve comprehension and the statistical efficacy of the analysis

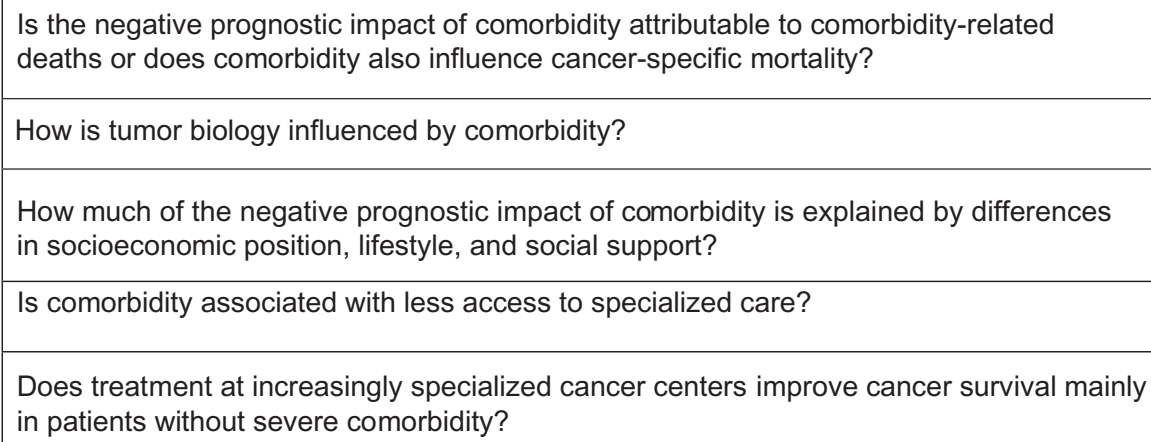

Figure $\mathbf{2}$ Some unanswered questions regarding the prognostic impact of comorbidity in cancer patients. 
(the prevalence of patients with high CCI scores is low in most study populations). The effect of the combined category is a weighted average of the individual scores. ${ }^{23}$ Analyses based on individual comorbid diseases would avoid these assumptions but are difficult to conduct, as they require much larger cohorts to identify subgroups with specific conditions of sufficient size. ${ }^{137}$ It must also be noted that virtually none of the studies under review examined the impact of duration and/or severity of comorbidity on cancer prognosis.

Most studies in our review were based on analyses of population-based cancer registry data linked with administrative data. Such data are generally adequate for determining prevalence of comorbidity and survival outcomes, but generally provide limited information on treatment delivery or patient tolerance for treatment regimens. Furthermore, studies relying on such databases may miss important comorbidities, underestimate their severity, or fail to address confounding factors such as smoking and other lifestyle factors. Thus, to improve research on comorbidity, studies should include information from different data sources (ie, administrative data, chart review, prescription records, and records of general practitioners) to provide more information on level and severity of comorbidity.

\section{Conclusion}

Despite increasing recognition of the impact of comorbid illnesses on the prognosis of cancer patients, challenges remain. A large number of studies reported suboptimal treatment among patients with comorbidity across tumor sites and stages of disease. However, because most studies examined diagnosis, treatment, physician and/or patient preferences, but not all factors, it is unclear whether suboptimal cancer treatment reflects appropriate consideration of increased risk of toxicity due to comorbid illness, patient preferences, lower quality of clinical care, or poor adherence. Consequently, a number of questions remain unanswered about the relationship between comorbidity and cancer outcome (Figure 2). To adequately address these questions, studies are needed that elucidate whether comorbidity in general or only specific diseases or disease combinations are associated with poorer survival. Thus, studies with a more specific focus should be undertaken, including those that address the impact of an individual comorbidity on treatment provided to a homogenous population of cancer patients (ie, with comparable stage and tumor type).

\section{Acknowledgments}

This review was conducted as part of the Aarhus University Disease Epidemiology and Outcomes (AUDEO) Program at the Department of Clinical Epidemiology, Aarhus University Hospital. This study received financial support from the Danish Cancer Society and the Department of Clinical Epidemiology's research foundation.

\section{Disclosure}

The authors report no conflicts of interest in this work.

\section{References}

1. Yancik R, Ries LA. Cancer in older persons: an international issue in an aging world. Semin Oncol. 2004;31(2):128-136.

2. Hutchins LF, Unger JM, Crowley JJ, Coltman CA Jr, Albain KS. Underrepresentation of patients 65 years of age or older in cancertreatment trials. N Engl J Med. 1999;341(27):2061-2067.

3. Biganzoli L, Wildiers H, Oakman C, et al. Management of elderly patients with breast cancer: updated recommendations of the International Society of Geriatric Oncology (SIOG) and European Society of Breast Cancer Specialists (EUSOMA). Lancet Oncol. 2012;13(4):e148-e160.

4. Cronin-Fenton DP, Nørgaard M, Jacobsen J, et al. Comorbidity and survival of Danish breast cancer patients from 1995 to $2005 . \mathrm{Br} J$ Cancer. 2007;96(9):1462-1468.

5. Iversen LH, Nørgaard M, Jacobsen J, Laurberg S, Sørensen HT. The impact of comorbidity on survival of Danish colorectal cancer patients from 1995 to 2006 - a population-based cohort study. Dis Colon Rectum. 2009;52(1):71-78.

6. Land LH, Dalton SO, Jensen MB, Ewertz M. Impact of comorbidity on mortality: a cohort study of 62,591 Danish women diagnosed with early breast cancer, 1990-2008. Breast Cancer Res Treat. 2012;131(3): $1013-1020$.

7. Asmis TR, Ding K, Seymour L, et al; National Cancer Institute of Canada Clinical Trials Group. Age and comorbidity as independent prognostic factors in the treatment of non small-cell lung cancer: a review of National Cancer Institute of Canada Clinical Trials Group trials. J Clin Oncol. 2008;26(1):54-59.

8. Roxburgh C, McDonald A, Salmond J, et al. Adjuvant chemotherapy for resected colon cancer: comparison of the prognostic value of tumour and patient related factors. Int J Colorectal Dis. 2011;26(4):483-492.

9. Sarfati D, Hill S, Blakely T, et al. The effect of comorbidity on the use of adjuvant chemotherapy and survival from colon cancer: a retrospective cohort study. BMC Cancer. 2009;9:116.

10. Grønberg BH, Sundstrøm S, Kaasa S, et al. Influence of comorbidity on survival, toxicity and health-related quality of life in patients with advanced non-small-cell lung cancer receiving platinum-doublet chemotherapy. Eur J Cancer. 2010;46(12):2225-2234.

11. Lüchtenborg M, Jakobsen E, Krasnik M, Linklater KM, Mellemgaard A, Møller $\mathrm{H}$. The effect of comorbidity on stage-specific survival in resected non-small cell lung cancer patients. Eur J Cancer. 2012;48(18): 3386-3395.

12. Last JM, editor. A Dictionary of Epidemiology. 4th ed. New York, NY: Oxford University Press; 2001.

13. Feinstein A. The pre-therapeutic classification of co-morbidity in chronic diseases. J Chronic Dis. 1970;23:455-468.

14. Barnett K, Mercer SW, Norbury M, Watt G, Wyke S, Guthrie B. Epidemiology of multimorbidity and implications for health care, research, and medical education: a cross-sectional study. Lancet. 2012;380(9836):37-43.

15. De Rijke JM, Schouten LJ, ten Velde GP M, W et al. Influence of age, comorbidity and performance status on the choice of treatment for patients with non-small cell lung cancer; results of a population-based study. Lung cancer (Amsterdam, Netherlands). 2004;46(2), 233-245.

16. Langer CJ. . Neglected and Underrepresented Subpopulations: Elderly and Performance Status 2 Patients with Advanced-Stage Non-Small-Cell Lung Cancer. Clinical Lung Cancer.2006; S126-S137. 
17. Quoix E. Optimal pharmacotherapeutic strategies for elderly patients with advanced non-small cell lung cancer. Drugs \& aging, 2011;28(11), 885-894.

18. Grose D, Devereux G, Brown L, et al; Scottish Lung Cancer Forum. Variation in comorbidity and clinical management in patients newly diagnosed with lung cancer in four Scottish centers. J Thorac Oncol. 2011;6(3):500-509.

19. Patterson RE, Flatt SW, Saquib N, et al. Medical comorbidities predict mortality in women with a history of early stage breast cancer. Breast Cancer Res Treat. 2010;122(3):859-865.

20. Ahern TP, Lash TL, Thwin SS, Silliman RA. Impact of acquired comorbidities on all-cause mortality rates among older breast cancer survivors. Med Care. 2009;47(1):73-79.

21. Lash TL, Mor V, Wieland D, Ferrucci L, Satariano W, Silliman RA. Methodology, design, and analytic techniques to address measurement of comorbid disease. J Gerontol A Biol Sci Med Sci. 2007;62(3): 281-285.

22. Charlson ME, Pompei P, Ales KL, MacKenzie CR. A new method of classifying prognostic comorbidity in longitudinal studies: development and validation. J Chronic Dis. 1987;40(5):373-383.

23. Lash TL. Collapsing high-end categories of comorbidity may yield misleading results. Clin Epidemiol. 2009;1:11-15.

24. Jørgensen TL, Hallas J, Friis S, Herrstedt J. Comorbidity in elderly cancer patients in relation to overall and cancer-specific mortality. $\mathrm{Br}$ J Cancer. 2012;106(7):1353-1360.

25. Bush D, Smith B, Younger J, Michaelson JS. The non-breast-cancer death rate among breast cancer patients. Breast Cancer Res Treat. 2011;127(1):243-249.

26. Schonberg MA, Marcantonio ER, Li D, Silliman RA, Ngo L, McCarthy EP. Breast cancer among the oldest old: tumor characteristics, treatment choices, and survival. J Clin Oncol. 2010;28(12):2038-2045.

27. Coebergh JW, Janssen-Heijnen ML, Post PN, Razenberg PP. Serious co-morbidity among unselected cancer patients newly diagnosed in the southeastern part of The Netherlands in 1993-1996. J Clin Epidemiol. 1999;52(12):1131-1136.

28. Patnaik JL, Byers T, Diguiseppi C, Denberg TD, Dabelea D. The influence of comorbidities on overall survival among older women diagnosed with breast cancer. J Natl Cancer Inst. 2011;103(14):1101-1011.

29. Tammemagi CM, Neslund-Dudas C, Simoff M, Kvale P. Impact of comorbidity on lung cancer survival. Int J Cancer. 2003;103(6): 792-802.

30. Irisa K, Masago K, Togashi Y, et al. Significance of pretreatment comorbidities in elderly patients with advanced non-small-cell lung cancer treated with chemotherapy or epidermal growth factor receptor-tyrosine kinase inhibitor. Med Oncol. 2012;29(1):185-192.

31. Janssen-Heijnen ML, Houterman S, Lemmens VE, Louwman MW, Maas HA, Coebergh JW. Prognostic impact of increasing age and comorbidity in cancer patients: a population-based approach. Crit Rev Oncol Hematol. 2005;55(3):231-240.

32. Houterman S, Janssen-Heijnen ML, Verheij CD, et al. Comorbidity has negligible impact on treatment and complications but influences survival in breast cancer patients. Br J Cancer. 2004;90(12):2332-2337.

33. Lemmens VE, van Halteren AH, Janssen-Heijnen ML, Vreugdenhil G, Repelaer van Driel OJ, Coebergh JW. Adjuvant treatment for elderly patients with stage III colon cancer in the southern Netherlands is affected by socioeconomic status, gender, and comorbidity. Ann Oncol. 2005;16(5):767-772.

34. Janssen-Heijnen ML, Lemmens VE, van den Borne BE, Biesma B, Oei SB, Coebergh JW. Negligible influence of comorbidity on prognosis of patients with small cell lung cancer: a population-based study in The Netherlands. Crit Rev Oncol Hematol. 2007;62(2):172-178.

35. Battafarano RJ, Piccirillo JF, Meyers BF, et al. Impact of comorbidity on survival after surgical resection in patients with stage I non-small cell lung cancer. J Thorac Cardiovasc Surg. 2002;123(2): 280-287.

36. Read WL, Tierney RM, Page NC, et al. Differential prognostic impact of comorbidity. J Clin Oncol. 2004;22(15):3099-3103.
37. Piccirillo JF, Tierney RM, Costas I, Grove L, Spitznagel EL Jr. Prognostic importance of comorbidity in a hospital-based cancer registry. JAMA. 2004;291(20):2441-2447.

38. Berglund A, Wigertz A, Adolfsson J, et al. Impact of comorbidity on management and mortality in women diagnosed with breast cancer. Breast Cancer Res Treat. 2012;135(1):281-289.

39. Riihimäki M, Thomsen H, Brandt A, Sundquist J, Hemminki K. Death causes in breast cancer patients. Ann Oncol. 2012;23(3): 604-610.

40. Kendal WS. Dying with cancer: the influence of age, comorbidity, and cancer site. Cancer. 2008;112(6):1354-1362.

41. van de Poll-Franse LV, Haak HR, Coebergh JW, Janssen-Heijnen ML, Lemmens VE. Disease-specific mortality among stage I-III colorectal cancer patients with diabetes: a large population-based analysis. Diabetologia. 2012;55(8):2163-2172.

42. Helweg-Larsen K. The Danish Register of Causes of Death. Scand J Public Health. 2011;39(Suppl 7):26-29.

43. Gjersøe P, Andersen SE, Mølbak AG, Wulff HR, Thomsen OO. Reliability of death certificates. The reproducibility of the recorded causes of death in patients admitted to departments of internal medicine. Ugeskr Laeger. 1998;160(35):5030-5034. Danish.

44. Wexelman BA, Eden E, Rose KM. Survey of New York City resident physicians on cause-of-death reporting, 2010. Prev Chronic Dis. 2013;10:E76.

45. Geraci JM, Escalante CP, Freeman JL, Goodwin JS. Comorbid disease and cancer: the need for more relevant conceptual models in health services research. J Clin Oncol. 2005;23(30):7399-7404.

46. Flores MB, Rocha GZ, Damas-Souza DM, et al. Obesity-induced increase in tumor necrosis factor- $\alpha$ leads to development of colon cancer in mice. Gastroenterology. 2012;143(3):741-753.

47. Forte V, Pandey A, Abdelmessih R, et al. Obesity, diabetes, the cardiorenal syndrome, and risk for cancer. Cardiorenal Med. 2012;2(2): 143-162.

48. Tsugane $\mathrm{S}$, Inoue $\mathrm{M}$. Insulin resistance and cancer: epidemiological evidence. Cancer Sci. 2010;101(5):1073-1079.

49. Sainz J, Rudolph A, Hoffmeister M, et al. Effect of type 2 diabetes predisposing genetic variants on colorectal cancer risk. J Clin Endocrinol Metab. 2012;97(5):E845-E851.

50. Nasca PC. Immunity and cancer risk. In: Nasca PC, Pastides H, editors. Fundamentals of Cancer Epidemiology. Sudbury, MA: Jones and Bartlett Publishers, Inc; 2008:334-358.

51. Hemminki K, Liu X, Ji J, Sundquist J, Sundquist K. Effect of autoimmune diseases on risk and survival in histology-specific lung cancer. Eur Respir J. 2012;40(6):1489-1495.

52. Takkouche B, Regueira-Méndez C, Etminan M. Breast cancer and use of nonsteroidal anti-inflammatory drugs: a meta-analysis. J Natl Cancer Inst. 2008;100(20):1439-1447.

53. Khuder SA, Herial NA, Mutgi AB, Federman DJ. Nonsteroidal antiinflammatory drug use and lung cancer: a metaanalysis. Chest. 2005;127(3):748-754.

54. Terry MB, Gammon MD, Zhang FF, et al. Association of frequency and duration of aspirin use and hormone receptor status with breast cancer risk. JAMA. 2004;291(20):2433-2440.

55. Bardia A, Olson JE, Vachon CM, et al. Effect of aspirin and other NSAIDs on postmenopausal breast cancer incidence by hormone receptor status: results from a prospective cohort study. Breast Cancer Res Treat. 2011;126(1):149-155.

56. Sassano A, Platanias LC. Statins in tumor suppression. Cancer Lett. 2008;260(1-2):11-19.

57. Thomsen RW, Farkas DK, Friis S, et al. Endocarditis and risk of cancer: a Danish nationwide cohort study. Am J Med. 2013;126(1):58-67.

58. Kwan ML, Habel LA, Slattery ML, Caan B. NSAIDs and breast cancer recurrence in a prospective cohort study. Cancer Causes Control. 2007;18(6):613-620.

59. Blair CK, Sweeney C, Anderson KE, Folsom AR. NSAID use and survival after breast cancer diagnosis in post-menopausal women. Breast Cancer Res Treat. 2007;101(2):191-197. 
60. Holmes MD, Chen WY, Li L, Hertzmark E, Spiegelman D, Hankinson SE. Aspirin intake and survival after breast cancer. J Clin Oncol. 2010;28(9):1467-1472.

61. Chan AT, Ogino S, Fuchs CS. Aspirin use and survival after diagnosis of colorectal cancer. JAMA. 2009;302(6):649-658.

62. Chlebowski RT, McTiernan A, Wactawski-Wende J, et al. Diabetes, metformin, and breast cancer in postmenopausal women. J Clin Oncol. 2012;30(23):2844-2852.

63. Kaplan MA, Pekkolay Z, Kucukoner M, et al. Type 2 diabetes mellitus and prognosis in early stage breast cancer women. Med Oncol. 2012;29(3):1576-1580.

64. Gonzalez EC, Ferrante JM, Van Durme DJ, Pal N, Roetzheim RG. Comorbid illness and the early detection of cancer. South Med J. 2001;94(9):913-920.

65. Extermann M. Interaction between comorbidity and cancer. Cancer Control. 2007;14:13-22.

66. Wheatley-Price P, Blackhall F, Thatcher N. The influence of sex in non-small cell lung cancer. Onkologie. 2009;32(10):547-548.

67. Shugarman LR, Mack K, Sorbero ME, et al. Race and sex differences in the receipt of timely and appropriate lung cancer treatment. Med Care. 2009;47(7):774-781.

68. Di Maio M, Signoriello S, Morabito A, et al. Prognostic impact of education level of patients with advanced non-small cell lung cancer enrolled in clinical trials. Lung Cancer. 2012;76(3):457-464.

69. Berglund A, Lambe M, Lüchtenborg M, et al. Social differences in lung cancer management and survival in South East England: a cohort study. BMJ Open. 2012;2(3):pii:e001048.

70. Dalton SO, Frederiksen BL, Jacobsen E, et al. Socioeconomic position, stage of lung cancer and time between referral and diagnosis in Denmark, 2001-2008. Br J Cancer. 2011;105(7):1042-1048.

71. Egeberg R, Halkjaer J, Rottmann N, Hansen L, Holten I. Social inequality and incidence of and survival from cancers of the colon and rectum in a population-based study in Denmark, 1994-2003. Eur J Cancer. 2008;44(14):1978-1988.

72. Aarts MJ, Voogd AC, Duijm LE, Coebergh JW, Louwman WJ. Socioeconomic inequalities in attending the mass screening for breast cancer in the south of The Netherlands - associations with stage at diagnosis and survival. Breast Cancer Res Treat. 2011;128(2): $517-525$.

73. Sheppard AJ, Chiarelli AM, Marrett LD, Nishri ED, Trudeau ME. Stage at diagnosis and comorbidity influence breast cancer survival in First Nations women in Ontario, Canada. Cancer Epidemiol Biomarkers Prev. 2011;20(10):2160-2167.

74. Hill S, Sarfati D, Blakely T, et al. Survival disparities in indigenous and non-indigenous New Zealanders with colon cancer: the role of patient comorbidity, treatment and health service factors. J Epidemiol Community Health. 2010;64(2):117-123.

75. Land LH, Dalton SO, Jørgensen TL, Ewertz M. Comorbidity and survival after early breast cancer. A review. Crit Rev Oncol Hematol. 2012;81(2):196-205.

76. Yasmeen S, Xing G, Morris C, Chlebowski RT, Romano PS. Comorbidities and mammography use interact to explain racial/ethnic disparities in breast cancer stage at diagnosis. Cancer. 2011;117(14):3252-3261.

77. Frederiksen BL, Osler M, Harling H, Ladelund S, Jørgensen T. Do patient characteristics, disease, or treatment explain social inequality in survival from colorectal cancer? Soc Sci Med. 2009;69(7):1107-1115.

78. Tammemagi CM, Nerenz D, Neslund-Dudas C, Feldkamp C, Nathanson D. Comorbidity and survival disparities among black and white patients with breast cancer. JAMA. 2005;294(14):1765-1772.

79. Dalton SO, Ross L, Düring M, et al. Influence of socioeconomic factors on survival after breast cancer - a nationwide cohort study of women diagnosed with breast cancer in Denmark, 1983-1999. Int J Cancer. 2007;121(11):2524-2531.

80. Gupta SK, Lamont EB. Patterns of presentation, diagnosis, and treatment in older patients with colon cancer and comorbid dementia. $J \mathrm{Am}$ Geriatr Soc. 2004;52(10):1681-1687.
81. Raji MA, Kuo YF, Freeman JL, Goodwin JS. Effect of a dementia diagnosis on survival of older patients after a diagnosis of breast, colon, or prostate cancer: implications for cancer care. JAMA Intern Med. 2008;168(18):2033-2040.

82. Vaeth PA, Satariano WA. Alcohol consumption and breast cancer stage at diagnosis. Alcohol Clin Exp Res. 1998;22(4):928-934.

83. Allemani C, Berrino F, Krogh V, et al. Do pre-diagnostic drinking habits influence breast cancer survival? Tumori. 2011;97(2): 142-148.

84. Desai MM, Bruce ML, Kasl SV. The effects of major depression and phobia on stage at diagnosis of breast cancer. Int J Psychiatry Med. 1999;29(1):29-45.

85. Fleming ST, Pursley HG, Newman B, Pavlov D, Chen K. Comorbidity as a predictor of stage of illness for patients with breast cancer. Med Care. 2005;43(2):132-140.

86. Kiefe CI, Funkhouser E, Fouad MN, May DS. Chronic disease as a barrier to breast and cervical cancer screening. J Gen Intern Med. 1998;13(6):357-365.

87. Rich AL, Tata LJ, Free CM, et al. How do patient and hospital features influence outcomes in small-cell lung cancer in England? Br J Cancer. 2011;105(6):746-752.

88. Cykert S, Dilworth-Anderson P, Monroe MH, et al. Factors associated with decisions to undergo surgery among patients with newly diagnosed early-stage lung cancer. JAMA. 2010;303(23):2368-2376.

89. Kennedy GD, Rajamanickam V, O'connor ES, et al. Optimizing surgical care of colon cancer in the older adult population. Ann Surg. 2011;253(3):508-514.

90. Rueth NM, Parsons HM, Habermann EB, et al. Surgical treatment of lung cancer: predicting postoperative morbidity in the elderly population. J Thorac Cardiovasc Surg. 2012;143(6):1314-1323.

91. Morris EJ, Taylor EF, Thomas JD, et al. Thirty-day postoperative mortality after colorectal cancer surgery in England. Gut. 2011;60(6):806-813.

92. Van Leeuwen BL, Rosenkranz KM, Feng LL, et al; Department of Surgical Oncology, MD Anderson Cancer Center. The effect of under-treatment of breast cancer in women 80 years of age and older. Crit Rev Oncol Hematol. 2011;79(3):315-320.

93. van Steenbergen LN, Rutten HJ, Creemers GJ, Pruijt JF, Coebergh JW, Lemmens VE. Large age and hospital-dependent variation in administration of adjuvant chemotherapy for stage III colon cancer in southern Netherlands. Ann Oncol. 2010;21(6):1273-1278.

94. Bradley CJ, Given CW, Dahman B, Fitzgerald TL. Adjuvant chemotherapy after resection in elderly Medicare and Medicaid patients with colon cancer. JAMA Intern Med. 2008;168(5):521-529.

95. Luo R, Giordano SH, Freeman JL, Zhang D, Goodwin JS. Referral to medical oncology: a crucial step in the treatment of older patients with stage III colon cancer. Oncologist. 2006;11(9):1025-1033.

96. Gross CP, Guo Z, McAvay GJ, Allore HG, Young M, Tinetti ME. Multimorbidity and survival in older persons with colorectal cancer. J Am Geriatr Soc. 2006;54(12):1898-1904.

97. Gray SW, Landrum MB, Lamont EB, McNeil BJ, Jaklitsch MT, Keating NL. Improved outcomes associated with higher surgery rates for older patients with early stage nonsmall cell lung cancer. Cancer. 2012;118(5):1404-1411.

98. Pasetto LM, Falci C, Basso U, et al. Adjuvant treatment for elderly patients with colon cancer. An observational study. Anticancer Res. 2008;28(4C):2513-2518.

99. Dy SM, Sharkey P, Herbert R, Haddad K, Wu AW. Comorbid illnesses and health care utilization among Medicare beneficiaries with lung cancer. Crit Rev Oncol Hematol. 2006;59(3):218-225.

100. O'Connor TL, Edge SB, Kossoff EB, et al. Factors affecting the delivery of adjuvant/neoadjuvant chemotherapy in older women with breast cancer. J Geriatr Oncol. 2012;3(4):320-328.

101. Booth CM, Shepherd FA, Peng Y, et al. Adjuvant chemotherapy for non-small cell lung cancer: practice patterns and outcomes in the general population of Ontario, Canada. J Thorac Oncol. 2012;7(3): $559-566$. 
102. Hu CY, Delclos GL, Chan W, Du XL. Assessing the initiation and completion of adjuvant chemotherapy in a large nationwide and population-based cohort of elderly patients with stage-III colon cancer. Med Oncol. 2011;28(4):1062-1074.

103. Hershman DL, Wang X, McBride R, Jacobson JS, Grann VR, Neugut AI. Delay in initiating adjuvant radiotherapy following breast conservation surgery and its impact on survival. Int J Radiat Oncol Biol Phys. 2006;65(5):1353-1360.

104. Gold HT, Do HT, Dick AW. Correlates and effect of suboptimal radiotherapy in women with ductal carcinoma in situ or early invasive breast cancer. Cancer. 2008;113(11):3108-3115.

105. Winget M, Hossain S, Yasui Y, Scarfe A. Characteristics of patients with stage III colon adenocarcinoma who fail to receive guidelinerecommended treatment. Cancer. 2010;116(20):4849-4856.

106. Punglia RS, Saito AM, Neville BA, Earle CC, Weeks JC. Impact of interval from breast conserving surgery to radiotherapy on local recurrence in older women with breast cancer: retrospective cohort analysis. BMJ. 2010;340:c845.

107. Davidoff AJ, Tang M, Seal B, Edelman MJ. Chemotherapy and survival benefit in elderly patients with advanced non-small-cell lung cancer J Clin Oncol. 2010;28(13):2191-2197.

108. Gross CP, McAvay GJ, Guo Z, Tinetti ME. The impact of chronic illnesses on the use and effectiveness of adjuvant chemotherapy for colon cancer. Cancer. 2007;109(12):2410-2419.

109. Earle CC, Neumann PJ, Gelber RD, Weinstein MC, Weeks JC. Impact of referral patterns on the use of chemotherapy for lung cancer. J Clin Oncol. 2002;20(7):1786-1792.

110. Birkmeyer NJ, Goodney PP, Stukel TA, Hillner BE, Birkmeyer JD. Do cancer centers designated by the National Cancer Institute have better surgical outcomes? Cancer. 2005;103(3):435-441.

111. Onega T, Duell EJ, Shi X, Demidenko E, Gottlieb D, Goodman DC Influence of NCI cancer center attendance on mortality in lung, breast, colorectal, and prostate cancer patients. Med Care Res Rev 2009;66(5):542-560.

112. Craft PS, Buckingham JM, Dahlstrom JE, et al. Variation in the management of early breast cancer in rural and metropolitan centres: implications for the organisation of rural cancer services. Breast. 2010;19(5):396-401.

113. Schonberg MA, Marcantonio ER, Ngo L, Silliman RA, McCarthy EP. Does life expectancy affect treatment of women aged 80 and older with early stage breast cancers? J Geriatr Oncol. 2012;3(1):8-16.

114. Gentil J, Dabakuyo TS, Ouedraogo S, Poillot ML, Dejardin O, Arveux P. For patients with breast cancer, geographic and social disparities are independent determinants of access to specialized surgeons. A eleven-year population-based multilevel analysis. $B M C$ Cancer. 2012;12(1):351.

115. Blais S, Dejardin O, Boutreux S, Launoy G. Social determinants of access to reference care centres for patients with colorectal cancer - a multilevel analysis. Eur J Cancer. 2006;42(17):3041-3048.

116. Krzyzanowska MK, Regan MM, Powell M, Earle CC, Weeks JC. Impact of patient age and comorbidity on surgeon versus oncologist preferences for adjuvant chemotherapy for stage III colon cancer. $\mathrm{JAm}$ Coll Surg. 2009;208(2):202-209.

117. O'Grady MA, Slater E, Sigurdson ER, et al. Assessing compliance with national comprehensive cancer network guidelines for elderly patients with stage III colon cancer: the Fox Chase Cancer Center Partners' initiative. Clin Colorectal Cancer. 2011;10(2):113-116.

118. Vinod SK, Sidhom MA, Gabriel GS, Lee MT, Delaney GP. Why do some lung cancer patients receive no anticancer treatment? J Thorac Oncol. 2010;5(7):1025-1032.

119. Keating NL, Landrum MB, Klabunde CN, et al. Adjuvant chemotherapy for stage III colon cancer: do physicians agree about the importance of patient age and comorbidity? J Clin Oncol. 2008;26(15):2532-2537.

120. Hamaker ME, Schreurs WH, Uppelschoten JM, Smorenburg CH. Breast cancer in the elderly: retrospective study on diagnosis and treatment according to national guidelines. Breast J. 2009;15(1):26-33.
121. Field TS, Doubeni C, Fox MP, et al. Under utilization of surveillance mammography among older breast cancer survivors. J Gen Intern Med. 2008;23(2):158-163.

122. van Gils CW, Koopman M, Mol L, Redekop WK, Uyl-de Groot CA, Punt CJ. Adjuvant chemotherapy in stage III colon cancer: guideline implementation, patterns of use and outcomes in daily practice in The Netherlands. Acta Oncol. 2012;51(1):57-64.

123. Gironés R, Torregrosa D, Gómez-Codina J, Maestu I, Tenias JM, Rosell R. Lung cancer chemotherapy decisions in older patients: the role of patient preference and interactions with physicians. Clin Transl Oncol. 2012;14(3):183-189.

124. Van Ryn M, Burke J. The effect of patient race and socio-economic status on physicians' perceptions of patients. Soc Sci Med. 2000;50(6): 813-828

125. Cavalli-Björkman N, Glimelius, B, Strang P. Equal cancer treatment regardless of education level and family support? A qualitative study of oncologists' decision-making. BMJ Open. 2012;2(4): pii:e001248

126. Siminoff LA, Graham GC, Gordon NH. Cancer communication patterns and the influence of patient characteristics: disparities in information-giving and affective behaviors. Patient Educ Couns. 2006;62(3):355-360.

127. Schonberg MA, Silliman RA, McCarthy EP, Marcantonio ER. Factors noted to affect breast cancer treatment decisions of women aged 80 and older. J Am Geriatr Soc. 2012;60(3):538-544.

128. Mandelblatt JS, Sheppard VB, Hurria A, et al; Cancer Leukemia Group B. Breast cancer adjuvant chemotherapy decisions in older women: the role of patient preference and interactions with physicians. J Clin Oncol. 2010;28(19):3146-3153.

129. Neugut AI, Matasar M, Wang X, et al. Duration of adjuvant chemotherapy for colon cancer and survival among the elderly. J Clin Oncol. 2006;24(15):2368-2375.

130. Barron TI, Connolly R, Bennett K, Feely J, Kennedy MJ. Early discontinuation of tamoxifen: a lesson for oncologists. Cancer. 2007;109(5):832-839.

131. McCowan C, Shearer J, Donnan PT, et al. Cohort study examining tamoxifen adherence and its relationship to mortality in women with breast cancer. Br J Cancer. 2008;99(11):1763-1768.

132. van Herk-Sukel MP, van de Poll-Franse LV, Voogd AC, Nieuwenhuijzen GA, Coebergh JW, Herings RM. Half of breast cancer patients discontinue tamoxifen and any endocrine treatment before the end of the recommended treatment period of 5 years: a population-based analysis. Breast Cancer Res Treat. 2010;122(3):843-851.

133. Hershman DL, Kushi LH, Shao T, et al. Early discontinuation and nonadherence to adjuvant hormonal therapy in a cohort of 8,769 earlystage breast cancer patients. J Clin Oncol. 2010;28(27):4120-4128.

134. Bickell NA, LePar F, Wang JJ, Leventhal H. Lost opportunities: physicians' reasons and disparities in breast cancer treatment. J Clin Oncol. 2007;25(18):2516-2521.

135. Hadji P, Ziller V, Kyvernitakis J, et al. Persistence in patients with breast cancer treated with tamoxifen or aromatase inhibitors: a retrospective database analysis. Breast Cancer Res Treat. 2013; 138(1):185-191.

136. Koroukian SM, Xu F, Bakaki PM, Diaz-Insua M, Towe TP, Owusu C. Comorbidities, functional limitations, and geriatric syndromes in relation to treatment and survival patterns among elders with colorectal cancer. J Gerontol A Biol Sci Med Sci. 2010;65(3):322-329.

137. Newschaffer CJ, Bush TL, Penberthy LE, Bellantoni M, Helzlsour K, Diener-West M. Does comorbid disease interact with cancer? An epidemiologic analysis of mortality in a cohort of elderly breast cancer patients. J Gerontol A Biol Sci Med Sci. 1998;53(5):M372-M378.

138. Lemmens VE, Janssen-Heijnen ML, Houterman S, et al. Which comorbid conditions predict complications after surgery for colorectal cancer? World J Surg. 2007;31(1):192-199.

139. Yood MU, Owusu C, Buist DS, et al. Mortality impact of less-thanstandard therapy in older breast cancer patients. J Am Coll Surg. 2008;206(1):66-75. 
140. Giordano SH, Duan Z, Kuo YF, Hortobagyi GN, Goodwin JS. Use and outcomes of adjuvant chemotherapy in older women with breast cancer. J Clin Oncol. 2006;24(18):2750-2756.

141. Buist DS, Ichikawa L, Prout MN, et al. Receipt of appropriate primary breast cancer therapy and adjuvant therapy are not associated with obesity in older women with access to health care. J Clin Oncol. 2007;25(23):3428-3436.

142. McCarthy EP, Ngo LH, Roetzheim RG, et al. Disparities in breast cancer treatment and survival for women with disabilities. Ann Intern Med. 2006;145(9):637-645.

143. Wang S, Wong ML, Hamilton N, Davoren JB, Jahan TM, Walter LC. Impact of age and comorbidity on non-small-cell lung cancer treatment in older veterans. J Clin Oncol. 2012;30(13):1447-1455.

144. Rich AL, Tata LJ, Free CM, et al. Inequalities in outcomes for non-small cell lung cancer: the influence of clinical characteristics and features of the local lung cancer service. Thorax. 2011;66(12):1078-1084.
145. Linn BS, Linn MW, Gurel L. Cumulative illness rating scale. $J$ Am Geriatr Soc. 1968;16(5):622-626.

146. Huang CW, Sun LC, Shih YL, et al. The impact on clinical outcome of high prevalence of diabetes mellitus in Taiwanese patients with colorectal cancer. World J Surg Oncol. 2012;10:76.

147. Nagel JM, Bücker S, Wood M, et al. Less advanced stages of colon cancer in patients with type 2 diabetes mellitus: an unexpected finding? Exp Clin Endocrinol Diabetes. 2012;120(4):224-228.

148. Pagano E, Filippini C, Di Cuonzo D, et al. Factors affecting pattern of care and survival in a population-based cohort of non-small-cell lung cancer incident cases. Cancer Epidemiol. 2010;34(4):483-489.

149. Klabunde CN, Legler JM, Warren JL, Baldwin LM, Schrag D. A refined comorbidity measurement algorithm for claims-based studies of breast, prostate, colorectal, and lung cancer patients. Annals of epidemiology.2007; 17(8), 584-90. 


\section{Supplementary material}

Table SI PubMed search strategy

\begin{tabular}{|c|c|c|}
\hline Subject & Query & $\begin{array}{l}\text { Articles } \\
\text { retrieved }\end{array}$ \\
\hline \multicolumn{3}{|l|}{ The cancer } \\
\hline 1 & “Colonic Neoplasms" [Majr] & 46042 \\
\hline 2 & “Breast Neoplasms” [Majr] & 162698 \\
\hline 3 & “Lung Neoplasms” [Majr] & 120655 \\
\hline \multicolumn{3}{|l|}{ Comorbidity } \\
\hline 4 & “Comorbidity” [MeSH] & 56994 \\
\hline 5 & Comorbid* & $9774 \mid$ \\
\hline 6 & Multimorbid* & 871 \\
\hline 7 & "Coexisting diseases" & 312 \\
\hline 8 & 4 OR 5 OR 6 OR 7 & 98580 \\
\hline 9 & “Diabetes Mellitus” [MeSH] & 285993 \\
\hline 10 & "Cardiovascular Diseases" [MeSH] & 1743728 \\
\hline II & $\begin{array}{l}\text { "Pulmonary Disease, Chronic } \\
\text { obstructive" [MeSH] }\end{array}$ & 18784 \\
\hline 12 & "Dementia" [MeSH] & 106404 \\
\hline 13 & 9 OR IO OR II OR I2 & $206385 I$ \\
\hline 14 & 8 OR 13 & 2137251 \\
\hline \multicolumn{3}{|l|}{ Outcome } \\
\hline 15 & Prognos* & 508580 \\
\hline 16 & Surviv* & 829260 \\
\hline 17 & Mortality & 761245 \\
\hline 18 & “Mortality” [MeSH] & 253258 \\
\hline 19 & I5 OR 16 OR 17 OR 18 & 1625050 \\
\hline $\begin{array}{l}\text { Combined colon } \\
\text { cancer query }\end{array}$ & I AND I4 AND 19 & 268 \\
\hline $\begin{array}{l}\text { Combined breast } \\
\text { cancer query }\end{array}$ & 2 AND I4 AND I9 & 1222 \\
\hline $\begin{array}{l}\text { Combined lung } \\
\text { cancer query }\end{array}$ & 3 AND I4 AND 19 & 1612 \\
\hline
\end{tabular}

Clinical Epidemiology

\section{Publish your work in this journal}

Clinical Epidemiology is an international, peer-reviewed, open access journal focusing on disease and drug epidemiology, identification of risk factors and screening procedures to develop optimal preventative initiatives and programs. Specific topics include: diagnosis, prognosis, treatment, screening, prevention, risk factor modification, systematic statical methods, evaluation of guidelines, translational medicine, health policies \& economic evaluations. The manuscript management system is completely online and includes a very quick and fair peer-review system, which is all easy to use.

\section{Dovepress}

\footnotetext{
Submit your manuscript here: http://www.dovepress.com/clinical-epidemiology-journal
} 